\title{
CP-arene oxides: the ultimate, active mutagenic forms of cyclopenta-fused polycyclic aromatic hydrocarbons (CP-PAHs)
}

\author{
María José Otero-Lobato ${ }^{a}$, Veronica E.M. Kaats-Richters ${ }^{\mathrm{a}}$, Carola Koper ${ }^{\mathrm{a}}$, Edward J. \\ Vlietstra $^{\mathrm{a}}$, Remco W.A. Havenith ${ }^{\mathrm{b}}$, Leonardus W. Jenneskens ${ }^{\mathrm{a}, *}$, Willem Seinen ${ }^{\mathrm{c}}$ \\ a Debye Institute, Department of Physical Organic Chemistry, Utrecht University, Padualaan 8, 3584 CH Utrecht, The Netherlands \\ ${ }^{\mathrm{b}}$ Debye Institute, Theoretical Chemistry Group, Utrecht University, Padualaan 8, 3584 CH Utrecht, The Netherlands \\ ${ }^{\mathrm{c}}$ Institute for Risk Assessment Science IRAS, Department of Toxicology, Utrecht University, P.O. Box 80176, 3508 TD Utrecht, The Netherlands
}

Received 23 August 2004; received in revised form 12 November 2004; accepted 27 November 2004

Available online 15 January 2005

\begin{abstract}
The bacterial mutagenic response (Ames-assay, Salmonella typhimurium strain TA98 \pm S9-mix) of a series of monocyclopentafused polycyclic aromatic hydrocarbons (CP-PAHs) identified in combustion exhausts, viz. cyclopenta[cd]pyrene (1), acephenanthrylene (2), aceanthrylene (3) and cyclopenta[hi]chrysene (4), is re-evaluated. The mutagenic effects are compared with those exerted by the corresponding partially hydrogenated derivatives, 3,4-dihydrocyclopenta[ $c d]$ pyrene (5), 4,5dihydroacephenanthrylene (6), 1,2-dihydroaceanthrylene (7) and 4,5-dihydrocyclopenta[hi]chrysene (8). It is shown that the olefinic bond of the externally fused five-membered ring of 1,3 and $\mathbf{4}$ is of importance for a positive mutagenic response. In contrast, whilst CP-PAH 2 is found inactive, its dihydro analogue (6) shows a weak metabolism-dependent response. The importance of epoxide formation at the external olefinic bond in the five-membered ring is substantiated by the bacterial mutagenic response of independently synthesized cyclopenta $[c d]$ pyrene-3,4-epoxide (9), acephenanthrylene-4,5-epoxide (10), aceanthrylene-1,2epoxide (11) and cyclopenta[hi]chrysene-4,5-epoxide (12). Their role as ultimate, active mutagenic forms, when CP-PAHs 1, 3 and 4 exhibit a positive mutagenic response, is confirmed. Semi-empirical Austin Model 1 (AM1) calculations on the formation of the CP-arene oxides (9-12) and their conversion into the monohydroxy-carbocations (9a-12a and 9b-12b) via epoxide-ring opening support our results. For $\mathbf{2}$ and $\mathbf{4}$, which also possess a bay-region besides an annelated cyclopenta moiety, the calculations rationalize that epoxidation at the olefinic bond of the cyclopenta moiety is favoured.
\end{abstract}

(C) 2004 Elsevier B.V. All rights reserved.

Keywords: Bacterial mutagenicity; Salmonella typhimurium; TA98; Cyclopenta-fused PAH; Epoxidation; Semi-empirical AM1 calculations

\footnotetext{
* Corresponding author. Tel.: +31302533128; fax: +31 302534533 .

E-mail address: 1.w.jenneskens@chem.uu.nl (L.W. Jenneskens).
}

\section{Introduction}

Cyclopenta-fused polycyclic aromatic hydrocarbons (CP-PAHs) are a special sub-class of PAHs, which contain (at least) one externally unsaturated 
five-membered ring annelated to a $\mathrm{PAH}$ perimeter. Their ubiquitous environmental presence due to incomplete combustion of fossil fuels $[1,2]$ and their enhanced bioactivity as compared with that of related PAH without the cyclopenta moiety, render CPPAHs of toxicological interest. Examples of PAH and corresponding CP-PAH are pyrene versus cyclopenta[ $c d]$ pyrene (1, Fig. 1) [3] and anthracene versus aceanthrylene (3) [4]. In most instances, biologically active CP-PAHs require exogenous metabolic activation (S9-mix) in order to exert positive mutagenic activity in bacterial mutagenicity assays (Ames-assay) $[4,5]$. One of the best studied representatives is cyclopenta[ $[c d]$ pyrene (1). It exhibits a high metabolismdependent mutagenic response in bacterial $[3,6]$ and human cell bioassays [7,8]. In addition, 1 also possesses tumour-initiating and moderate carcinogenic potential [9-11].

Although for common PAHs, a bay-region has been postulated as a prerequisite to exert bioactivity in the presence of exogenous metabolic activation (S9-mix [12]), 1 and other known bioactive CP-PAHs lack this structural feature. In these cases, epoxidation of the olefinic bond in the five-membered ring via oxidative metabolic activation by cytochrome $\mathrm{P} 450$ isoenzymes in the S9-mix, is considered to give the putative ultimate, active mutagenic forms of CP-PAHs [3]. Note that for some CP-PAHs, which also contain a bay-region in their PAH core, it has been suggested that epoxidation of the cyclopenta moiety accounts for the observed bacterial mutagenic activity [13,14]. The facile formation of epoxides at the five-membered ring is supported in the case of $\mathbf{1}$ by the isolation of dihydrodiols (derived from the action of the epoxide-hydrolase on the epoxide) in metabolic studies with liver microsomes ([15], see however also references [16,17] in which bio-activation of PAH dihydro-diols by sulfonation is reported), as well as the reaction of the epoxides with DNA in vitro (isolation of DNA-adducts) [18-22]. The importance of the olefinic bond in the five-membered ring is substantiated by the observation that dihydro-CP-PAH derivatives, which contain a saturated five-membered ring, generally exhibit no mutagenic activity in bacterial bioassays $[7,23,24]$. Interestingly, tentative results indicate that epoxidation of the olefinic bond in the cyclopenta moiety in contrast to the parent bioactive CP-PAH, leads to direct-acting bacterial mutagens (without the need for an exogenous metabolic activation mixture, - S9-mix, see below) that exert cytotoxicity at high concentrations $[25,26]$.

Previously, CP-PAHs 1-4 have been assayed for mutagenicity using different strains of Salmonella typhimurium in the Ames-assay (TA98, TA100, etc.). Whilst 1 was found to be active, $\mathbf{2}$ was inactive [27]. However, $\mathbf{2}$ was found active with metabolic activation in the forward mutation assay (strain TM 677) [7,23]. Compounds 3 [4,27] and 4 [5] have been reported to act as bacterial mutagens upon metabolic activation. In the case of $\mathbf{4}$, the diols at the cyclopenta-ring and at the bay-region have been isolated and identified as active metabolites [5]. For CP-PAHs showing a positive metabolism-dependent mutagenic response, the epoxides at the annelated five-membered ring, i.e. 9-12 from 1 to 4 , respectively (Fig. 1), are proposed as the ultimate, active mutagenic forms. Nevertheless, so far only epoxides $\mathbf{9}$ and $\mathbf{1 1}$ have been synthesized and previously assayed for their bacterial mutagenic response [15,27].

Hence, the high genotoxicity observed with some CP-PAHs on the one hand, and, on the other hand, the lack of bioactivity reported for other such compounds in the different bacterial systems earlier employed, have prompted us to re-evaluate in a single systematic study the bacterial mutagenic response of the CP-PAHs 1-4. These compounds all represent unequivocally identified combustion exhaust constituents $[28,29]$. To establish the importance of the olefinic bond at the five-membered ring for metabolic activation, the related dihydro-CP-PAHs 5-8 were synthesized and assayed for mutagenic activity in this study. Furthermore, the epoxides 9-12 were synthesized and their mutagenic activity compared to that of 1-4 in order to evaluate their potential role as ultimate, active mutagenic forms. The experimental results are supported by semi-empirical Austin Model 1 (AM1) calculations [30] on the epoxides 9-12 and their related monohydroxy-carbocations $\mathbf{9 a - 1 2 a}$ and $\mathbf{9 b}-\mathbf{1 2 b}$ obtained via the epoxide-ring opening (Fig. 1).

\section{Materials and methods}

\subsection{Chemicals}

The CP-PAHs cyclopenta[ $c d]$ pyrene (1, CAS no. 27208-37-3), acephenanthrylene (2, CAS no. 201-06- 


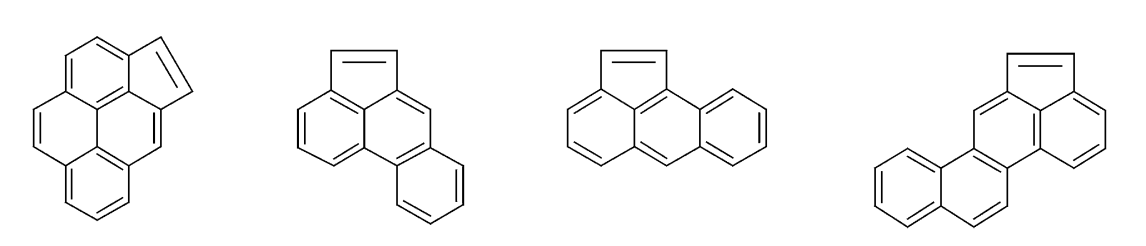

89000000

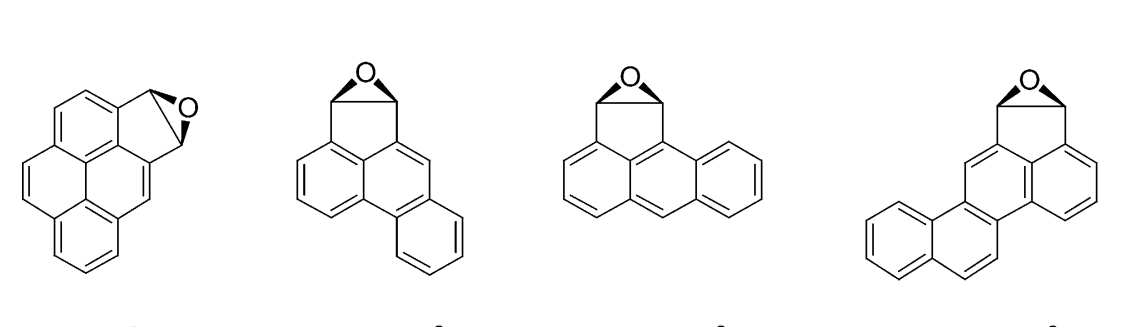

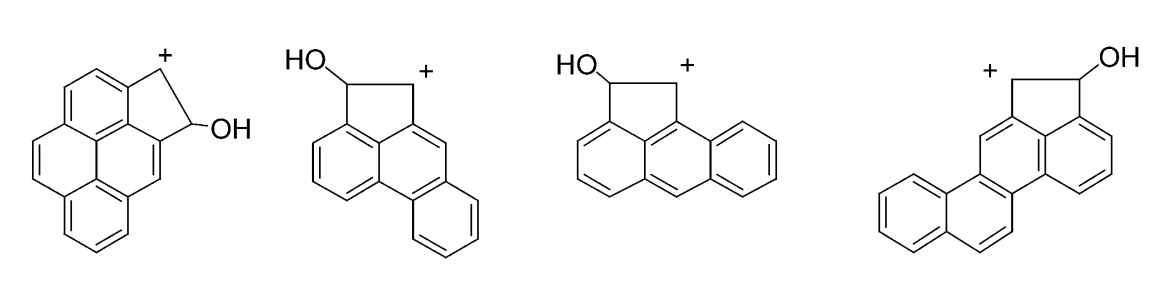

of 
9), aceanthrylene (3, CAS no. 202-03-9) and cyclopenta[hi]chrysene (4, CAS no. 216-48-8), their related partially hydrogenated derivatives 3,4-dihydrocyclopenta[cd]pyrene (5, CAS no. 25732-74-5), 4,5,dihydroacephenanthrylene (6, CAS no. 6232-48-0), 1,2-dihydroaceanthrylene (7, CAS no. 641-48-5) and 4,5-dihydrocyclopenta[hi]chrysene (8, CAS no. 4766-40-9), and their corresponding monoepoxides at the externally fused cyclopenta moiety cyclopenta $[c d]$ pyrene-3,4-epoxide (9, CAS no. 7347354-8), acephenanthrylene-4,5-epoxide (10, CAS no. 133733-26-3), aceanthrylene-1,2-epoxide (11, CAS no. 133733-25-2) and cyclopenta[hi]chrysene-4,5epoxide (12, CAS no. 139469-80-0) were synthesized as described in the Section 2.3. The purity of all compounds was at least $>98.9 \%$ (capillary GC). The positive controls benzo $[a]$ pyrene $(\mathrm{B}[a] \mathrm{P}, 98.8 \%$, CAS no. 50-32-8) and 1-nitropyrene (1-NP, 99\%, CAS no. 5522-43-0) were purchased from Sigma-Aldrich and used without further purification. Dimethyl sulfoxide (DMSO, 99.9\%, CAS no. 67-68-5) was purchased from Aldrich, and NADP monosodium salt (98\%, CAS no. 1184-16-3), D-glucose-6-phosphate anhydrous (G-6-P 99\%, CAS no. 56-73-5) and potassium monopersulfate triple salt (caroate, CAS no. 37222-66-5) were from Sigma.

\subsection{Bacterial mutagenicity assays}

The bacterial mutagenic response was determined with the histidine (His)-reversion assay (S. typhimurium strain TA98) according to the standard protocol by Ames and coworkers [30,31], both in the absence and in the presence of an exogenous metabolic activation system ( \pm S9-mix). The $\mathrm{S} 9$-mix consisted of rat-liver microsome preparations (S9-fraction) obtained from Aroclor-1254-treated male Wistar rats and NADPH-generating co-factors using the standard procedures $[31,32]$. The total protein content and the activity of the cytochrome $\mathrm{P} 450$ isoenzyme P450-1A were determined to be $29.15 \mathrm{mg} / \mathrm{ml}$ (Lowry method) [33] and $51.58 \mathrm{pmol} / \mathrm{ml} / \mathrm{min} / \mathrm{mg}$ protein (ethoxyresorufin $O$-deethylase (EROD) method) [34], respectively.

Compounds 1-8 were dissolved in DMSO $(500 \mu \mathrm{g} / \mathrm{ml})$ and tested at five different concentrations (1-4; 0.0, 1.0, 2.0, 4.0, 8.0, 12.0 and $20.0 \mu \mathrm{g} /$ plate and 5-8; $0.0,1.0,5.0,15.0$ and $20.0 \mu \mathrm{g} /$ plate). Note that compounds $\mathbf{9}-\mathbf{1 2}$ could only be tested up to $2.0 \mu \mathrm{g} /$ plate (concentrations $0.0,0.1,0.5,1.5$ and $2.0 \mu \mathrm{g} /$ plate) due to their extreme cytotoxicity (see Section 3). Parallel experiments were carried out with (+S9-mix 2\%, $\mathrm{v} / \mathrm{v}, 0.29 \mathrm{mg}$ protein/plate) and without exogenous metabolic activation mixture $(-\mathrm{S} 9-\mathrm{mix})$ with three plates per test dose, in at least two independent experiments. Positive controls, i.e. 1-NP, $5.0 \mu \mathrm{g} /$ plate (-S9mix, $>1000$ revertants (rev.)) and $\mathrm{B}[a] \mathrm{P}, 6.0 \mu \mathrm{g} /$ plate (+S9-mix, $133.9 \pm 20.5$ rev.), negative controls, i.e. DMSO (-S9-mix, 10.2 $\pm 4.7,+$ S9-mix, $19.8 \pm 6.5$ rev.) and spontaneous reversion His revertants $(-\mathrm{S} 9$ mix, $13.3 \pm 4.7,+$ S9-mix, $21.6 \pm 6$ rev.) for TA98 were included in each experiment. The plates were incubated at $37^{\circ} \mathrm{C}$ for $48 \mathrm{~h}$ and the His revertant colonies were counted manually. The results are presented in dose-response curves and are expressed as mean values of His revertant colonies per dose of test compound of three different plates from two independent experiments without correction for spontaneous reversion. To establish a positive mutagenic response the following criteria were used [35,36]: (i) a three-fold increase of His revertants in plates with test compound as compared with the negative control DMSO, (ii) ascending dose-response curves and (iii) reproducibility of the results in at least two independent experiments. Note that several studies have demonstrated that the first criterion by itself is insufficient to establish a positive mutagenic response [37]. Specific mutagenic activities, i.e. the number of His revertants induced per nmol of test compound (Table 1), were calculated by least squares regression from the initial ascending portion of the dose-response curves. The actual data for each dose of test compound (mean value from at least six plates \pm standard deviation) and the correlation coefficients from the calculation of the slopes of each dose-response curve are reported in Appendix A (Tables A.1-A.3).

\subsection{Synthesis}

With the exception of the epoxidation reactions all other reactions were carried out under a $\mathrm{N}_{2}$ atmosphere. Solvents were dried and purified using standard protocols. Commercial reagents were used as received. Column and flash chromatography were performed on Merk kieselgel 60 silica (230-400 ASTM) and neutral aluminium oxide W200. Thin-layer chromatography (TLC) was carried out using TLC sheets of alu- 
Table 1

Specific mutagenic activities ${ }^{\mathrm{a}}$ (His revertants/nmol) and mutagenic potency ${ }^{\mathrm{b}}$ of 1-12 (see Fig. 1)

\begin{tabular}{|c|c|c|c|c|}
\hline \multirow[t]{2}{*}{ Compound } & \multicolumn{2}{|c|}{ TA98 + S9-mix 2\% (v/v) } & \multicolumn{2}{|l|}{ TA98 - S9-mix } \\
\hline & His revertants/nmol & Mutagenic potency $^{\mathrm{b}}$ & His revertants/nmol & Mutagenic potency $^{\mathrm{b}}$ \\
\hline 1 & 64.6 & +++ & 0.5 & - \\
\hline 5 & $\sim 0.05$ & - & $\sim 0.05$ & - \\
\hline 9 & 61.8 & +++ & 61.0 & +++ \\
\hline 2 & 0.4 & - & 0.2 & - \\
\hline 6 & 1.1 & + & $\sim 0.05$ & - \\
\hline 10 & 1.0 & $-/+$ & 2.5 & + \\
\hline 3 & 2.4 & + & 0.2 & - \\
\hline 7 & $\sim 0.05$ & - & $\sim 0.05$ & - \\
\hline 11 & $-{ }^{c}$ & $-^{c}$ & $-{ }^{c}$ & $-^{c}$ \\
\hline 4 & 1.2 & + & 0.2 & - \\
\hline 8 & $\sim 0.05$ & - & $\sim 0.05$ & - \\
\hline 12 & 2.8 & + & 11.3 & ++ \\
\hline
\end{tabular}

a Calculated by least squares regression from the initial ascending linear portion of dose-response curves (Figs. 2-5). For 1-8, the dose range $0.0-20.0 \mu \mathrm{g} /$ plate was used (see Section 2.2).

b Mutagenic potency: (-) negative, (+) weakly positive, (+++) highly positive.

c The mutagenic activity of epoxide $\mathbf{1 1}$ could not be determined due to its high cytotoxicity.

minium oxide $60 \mathrm{~F}_{254}$ neutral (type $\mathrm{E}$ ) or TLC silica gel $60 \mathrm{~F}_{254}$. Melting points are uncorrected. ${ }^{1} \mathrm{H}$ and ${ }^{13} \mathrm{C}$ NMR spectra were recorded on either a Bruker AC 300 or a Varian Unity Inova Spectrometer operating at 300.13 and $75.47 \mathrm{MHz}$, respectively, at $25^{\circ} \mathrm{C}$ with solvents $\mathrm{d}_{6}$-acetone or $\mathrm{CDCl}_{3}$. Chemical shifts values are reported in ppm and are referred to TMS. $J$-values are given in $\mathrm{Hz}$ (multiplicity: s: singlet, d: doublet, t: triplet, dd: double doublet and m: multiplet). Capillary GC chromatograms were obtained in a Varian GC 3350 and GC 3400: capillary column DB 5 (length $30 \mathrm{~m}$, i.d. $0.3 \mathrm{~mm}$ and $1-\mu \mathrm{m}$ film thickness), temperature program $\left(T_{\mathrm{i}}=200\right.$ or $250^{\circ} \mathrm{C}$, isothermal for $10 \mathrm{~min}$, heating to $280{ }^{\circ} \mathrm{C}$ at $10^{\circ} \mathrm{C} \mathrm{min}^{-1}$ ), injector and detector temperature $300^{\circ} \mathrm{C}$ and $\mathrm{He}$ as carrier gas. GC/mass spectrometer (MS) spectra were measured on a ATI Unicam Automass System 2 quadruple mass spectrometer: J \& W Scientific DB-15 ms capillary column (length $30 \mathrm{~m}$, i.d. $0.25 \mathrm{~mm}$ and 0.25 $\mathrm{mm}$ film thickness), temperature program $\left(T_{\mathrm{i}}=200\right.$ or $250^{\circ} \mathrm{C}$, isothermal for $10 \mathrm{~min}$, heating to $280^{\circ} \mathrm{C}$ at $10^{\circ} \mathrm{C} \mathrm{min}^{-1}$ ), injector temperature $300^{\circ} \mathrm{C}$ and $\mathrm{He}$ as carrier gas. Mass spectrometer: EI $70 \mathrm{eV}$.

\subsubsection{CP-PAHs $1-4$}

Compounds 1-4 were synthesized employing Flash Vacuum Thermolysis (FVT) as described previously [37-40]. A Thermolyne 21100 tube furnace containing an unpacked quartz tube $(40 \mathrm{~cm}$ long, diameter $2.5 \mathrm{~cm}$ ) was used at $T=900-1050{ }^{\circ} \mathrm{C}, p<0.01 \mathrm{mmHg}$.

Table 2

Semi-empirical AM1 energy difference ( $\Delta E$ in $\mathrm{kcal} / \mathrm{mol}$ ) of the epoxides 9-12 and the two possible monohydroxy-carbocations $(\mathbf{9 a}-\mathbf{1 2} \mathbf{a}$ and 9b-12b, see Fig. 1)

\begin{tabular}{llll}
\hline Compound & $\Delta E$ (monoepoxides) $^{\mathrm{a}}$ & \multicolumn{2}{c}{$\Delta E$ (monohydroxy-carbocations) $^{\mathrm{b}}$} \\
\cline { 2 - 3 } & & $\mathbf{a}$ & $\mathbf{b}$ \\
\hline $\mathbf{9}$ & -18.7 & 131.5 & 137.9 \\
$\mathbf{1 0}$ & -18.0 & 138.8 & 139.5 \\
$\mathbf{1 1}$ & -17.8 & 128.7 & 137.2 \\
$\mathbf{1 2}$ & -18.1 & 135.3 & 138.2 \\
\hline
\end{tabular}

a $\Delta E$ (monoepoxide $)=\Delta H_{\mathrm{f}}^{\circ}($ monoepoxide $(\mathbf{9}-\mathbf{1 2}))-\Delta H_{\mathrm{f}}^{\circ}(\mathbf{1}-\mathbf{4})($ Fig. 1).

${ }^{\mathrm{b}}$ Estimate for $\Delta E$ (monohydroxy-carbocation formation $)=\Delta H_{\mathrm{f}}^{\circ}($ monohydroxy-carbocation $(\mathbf{9 a}-\mathbf{1 2 a}$ or $\mathbf{9 b}-\mathbf{1 2 b}))-\Delta H_{\mathrm{f}}^{\circ}(\mathbf{9}-\mathbf{1 2})($ Fig. 1$)$. 


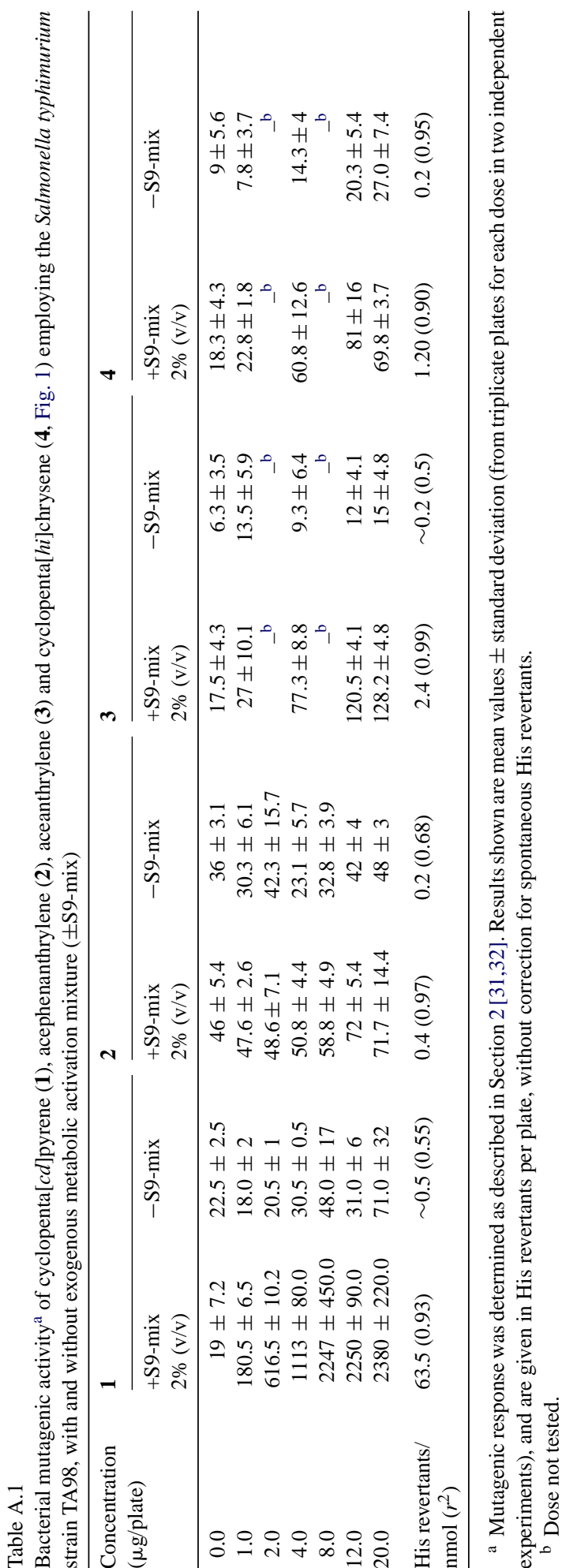

The product mixture (pyrolysate) deposited just behind the furnace was recovered with dry $\mathrm{CH}_{2} \mathrm{Cl}_{2}$ (ca. $3 \mathrm{ml}$ ). After concentration of the solution in vacuo the pyrolysate was subjected to analysis $\left({ }^{1} \mathrm{H}\right.$ and ${ }^{13} \mathrm{C} \mathrm{NMR}$, $\mathrm{GC}, \mathrm{GC} / \mathrm{MS}$ ) before further purification. Pure CPPAHs 1-4 for the mutagenicity assays (Ames-assay) or as precursors for further conversions were isolated from the pyrolysates by re-crystallization or column chromatography as described previously [38-41]. The ${ }^{1} \mathrm{H}$ and ${ }^{13} \mathrm{C}$ NMR spectra and GC/MS data of the isolated CP-PAHs 1-4 were in accordance with those previously reported $[38,40,41]$.

\subsubsection{Dihydro-CP-PAHs 5-8}

Compounds 5-8 were prepared by heterogeneous catalytic hydrogenation of the corresponding CP-PAHs 1-4 (ca. $20 \mathrm{mg}$ ) with hydrogen $\left(p_{\mathrm{H}_{2}} / 1 \mathrm{~atm}\right)$ and $\mathrm{Pd}$ on activated carbon $(2 \mathrm{mg})$ in dry THF $(15 \mathrm{ml})$ at room temperature [42]. The heterogeneous reaction mixtures were subjected to work-up after the intense colour of the original CP-PAH solution had disappeared $(2-3 \mathrm{~h})$. The reaction mixture was filtered over Celite and the filtrate was concentrated under reduced pressure giving pure dihydro-CP-PAHs 5-8 as colourless solids in near quantitative yield. The analytical and spectral data of 5-8 are reported in Appendix A (see also [43-46]).

\subsubsection{Epoxides $\mathbf{9 - 1 2}$}

Epoxidation of 1-4 at the olefinic bond of the external five-membered ring was carried out using a fresh solution of dimethyldioxirane in acetone prepared according to literature procedures $[47,48]$. Usually, $50-70 \mathrm{ml}$ of $0.07-0.10 \mathrm{M}$ dimethyldioxirane solutions in acetone were obtained. The dimethyldioxirane content was assessed by monitoring the oxidation of methyl phenyl sulfide into its sulfoxide derivative by calibrated capillary GC. The synthesis of the epoxides 9-12 was carried out at room temperature in the dark using the CP-PAHs 1-4 on a $\mathrm{mg}$ scale (80-100 mmol), with a 1.5 - to 2.0 -fold molar excess of a fresh dimethyldioxirane solution in acetone, in the presence of an equimolar amount of $\mathrm{NaHCO}_{3}$. After complete consumption of the CP-PAH, the reaction mixture was filtered and the filtrate was concentrated in vacuo. The crude product was dissolved in either acetone or dichloromethane, dried over $\mathrm{MgSO}_{4}$ and filtered. Concentration of the filtrate in vacuo gave analytically pure samples of the epoxides 9-12 in a near 
quantitative yield. The analytical and spectral data of 5-8 are reported in Appendix A.

\subsection{Computations}

To obtain estimates of the heats of formation $\left(\Delta H_{\mathrm{f}}^{\circ}\right.$ in $\mathrm{kcal} / \mathrm{mol}$ ) of the compounds $\mathbf{1 - 1 3}$ and $\mathbf{1 5} \mathbf{a}-\mathbf{c}$ as well as the monohydroxyl-carbocation species 9a-12a, 14a, 16a-18a, 9b-12b, 14b and 16b-18b, shown in Figs. 1 and 6, semi-empirical restricted Hartree-Fock AM1 calculations (RHF/AM1) [30] were performed using the general-purpose semi-empirical molecular orbital package for the study of chemical structures and reactions, viz. the MOPAC 7.0 program, with the eigenvector-following $(\mathrm{EF})$ routine until the gradient norm $(\mathrm{GNORM})<0.05$. All geometries were optimised without imposing any geometry constraints. All computed minima were characterized by Hessian calculations; in all cases no imaginary frequencies were found.

\section{Results}

The CP-PAHs cyclopenta[ $[c d]$ pyrene (1), acephenanthrylene (2), aceanthrylene (3) and cyclopenta[hi]chrysene (4) as well as the related dihydro-CPPAHs 3,4-dihydrocyclopenta[cd]pyrene (5), 4,5-dihy-
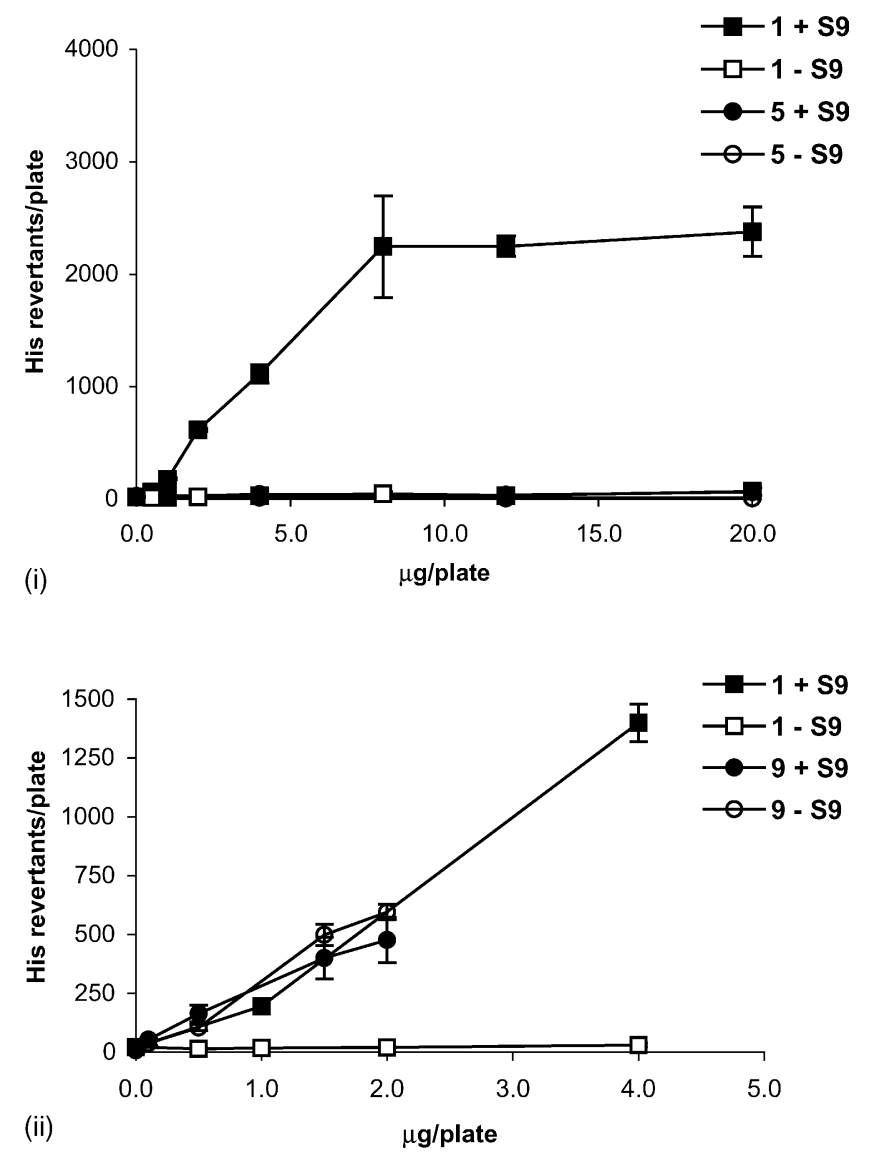

Fig. 2. Comparison of the dose-response curves of (i) cyclopenta[cd]pyrene (1, (ם): $+\mathrm{S} 9$-mix 2\%, v/v, ( $\square)$ : $-\mathrm{S} 9$-mix) and its corresponding 3,4-dihydrocyclopenta $[c d]$ pyrene $(\mathbf{5},(\mathbf{O}):+\mathrm{S} 9$-mix $2 \%$, v/v, $(\bigcirc)$ : $-\mathrm{S} 9$-mix) and (ii) cyclopenta[cd]pyrene $(\mathbf{1},(\mathbf{\square}):+\mathrm{S} 9-\mathrm{mix} 2 \%, \mathrm{v} / \mathrm{v},(\square)$ : -S9-mix) and its corresponding cyclopenta[cd]pyrene-3,4-epoxide $(\mathbf{9},(\mathbf{O}):+\mathrm{S} 9$-mix $2 \%$, v/v, $(\bigcirc)$ : $-\mathrm{S} 9$-mix). (Note the different scales for the His revertants/plate in (i) and (ii). Furthermore, in (ii), the concentration range is $0.0-2.0 \mu \mathrm{g} /$ plate for $\mathbf{9}$, see text.) The standard protocol by Ames and coworkers [31,32] was followed using the S. typhimurium strain TA98. 

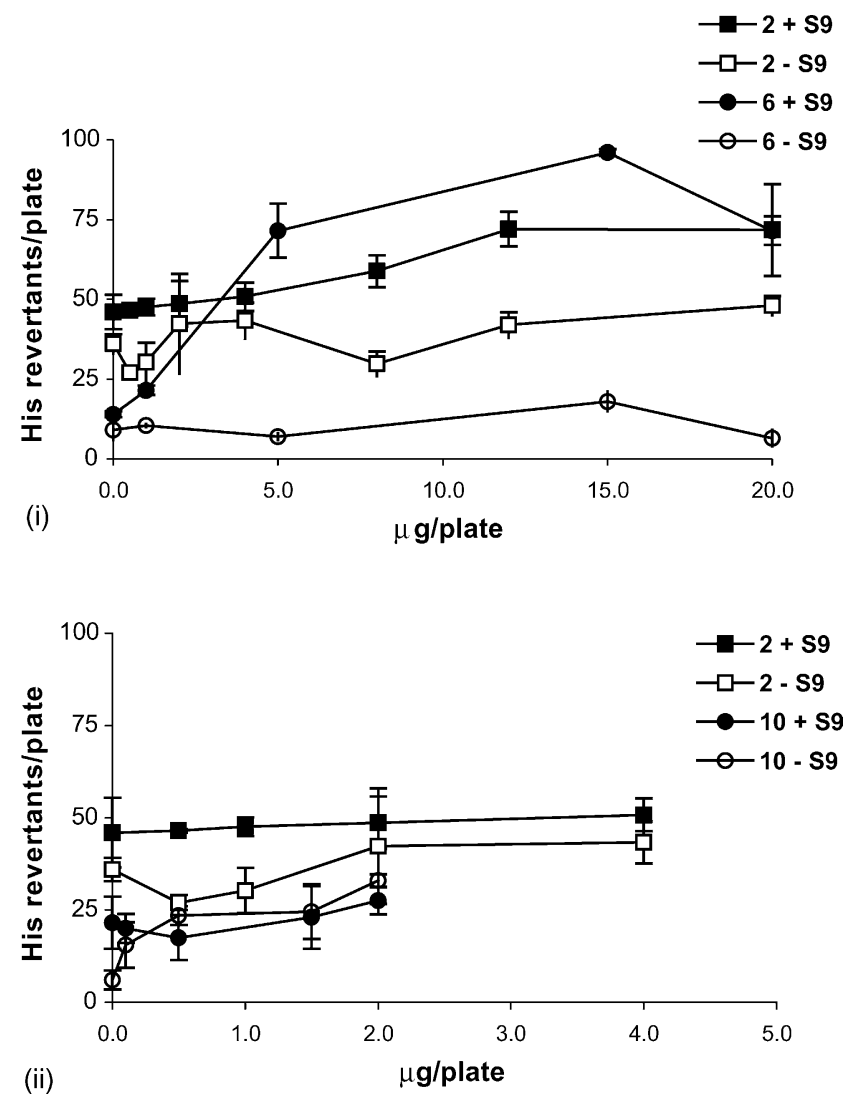

Fig. 3. Comparison of the dose-response curves of (i) acephenanthrylene $(\mathbf{2},(\mathbf{\square}):+\mathrm{S} 9-\operatorname{mix} 2 \%$, v/v, ( $\square$ ): $-\mathrm{S} 9$-mix) and its corresponding

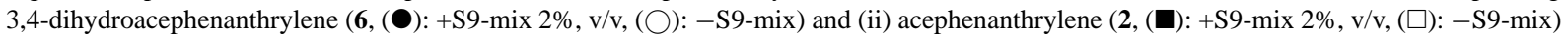
and its corresponding acephenanthrylene-3,4-epoxide $(\mathbf{1 0},(\mathbf{O}):+\mathrm{S} 9-\operatorname{mix} 2 \%, \mathrm{v} / \mathrm{v},(\mathrm{O}):-\mathrm{S} 9-\mathrm{mix})$. (Note that in (ii), the concentration range is $0.0-2.0 \mu \mathrm{g} /$ plate for 10, see text.) The standard protocol by Ames and coworkers [31,32] was followed using the S. typhimurium strain TA98.

droacephenanthrylene (6), 1,2-dihydroaceanthrylene (7) and 4,5-dihydrocyclopenta[hi]chrysene (8, Fig. 1) in which the olefinic bond at the cyclopenta moiety is selectively hydrogenated (see Section 2.3), were evaluated for mutagenicity in the Ames-test with the S. typhimurium auxotropic strain TA98, with and without the optimal amount of exogenous activation mixture (S9-mix $2 \%, \mathrm{v} / \mathrm{v})$, in the concentration range $0.0-20.0 \mu \mathrm{g} /$ plate. Dose-response curves are shown in the top part (i) of Figs. 2-5. The epoxides of 1-4, viz. cyclopenta[ $[c d]$ pyrene-3,4-epoxide $(\mathbf{9})$, acephenanthrylene-4,5-epoxide (10), aceanthrylene1,2-epoxide (11) and cyclopenta[hi]chrysene-4,5epoxide (12, Fig. 1) were synthesized employing a dimethyldioxirane solution in acetone as a mild epoxidation agent [49] (see Section 2.3). Note that the mutagenic response of the epoxides 9-12 could only be assayed in the range $0.0-2.0 \mu \mathrm{g} /$ plate due to the high toxicity encountered at higher concentrations. The dose-response curves of the epoxides are compared with those obtained for the parent compounds in the same concentration range (Figs. 2-5). The specific mutagenic activity of $\mathbf{1 - 1 2}$ is reported in Table 1 .

In Fig. 2, the mutagenic response for $\mathbf{1}$ is presented and compared with that of its dihydro (5) and epoxide (9) derivatives, respectively. As expected [3], 1 exhibits a high specific mutagenic activity in the presence of the metabolic activation mixture (+S9-mix 2\%, v/v, 64.6 His revertants/nmol, Table 1), but it is not mutagenic in the absence of S9-mix. Whilst $\mathbf{5}$ is inactive both with and without $S 9$-mix, epoxide $\mathbf{9}$ is a potent mutagen both with and without activation mixture (specific 

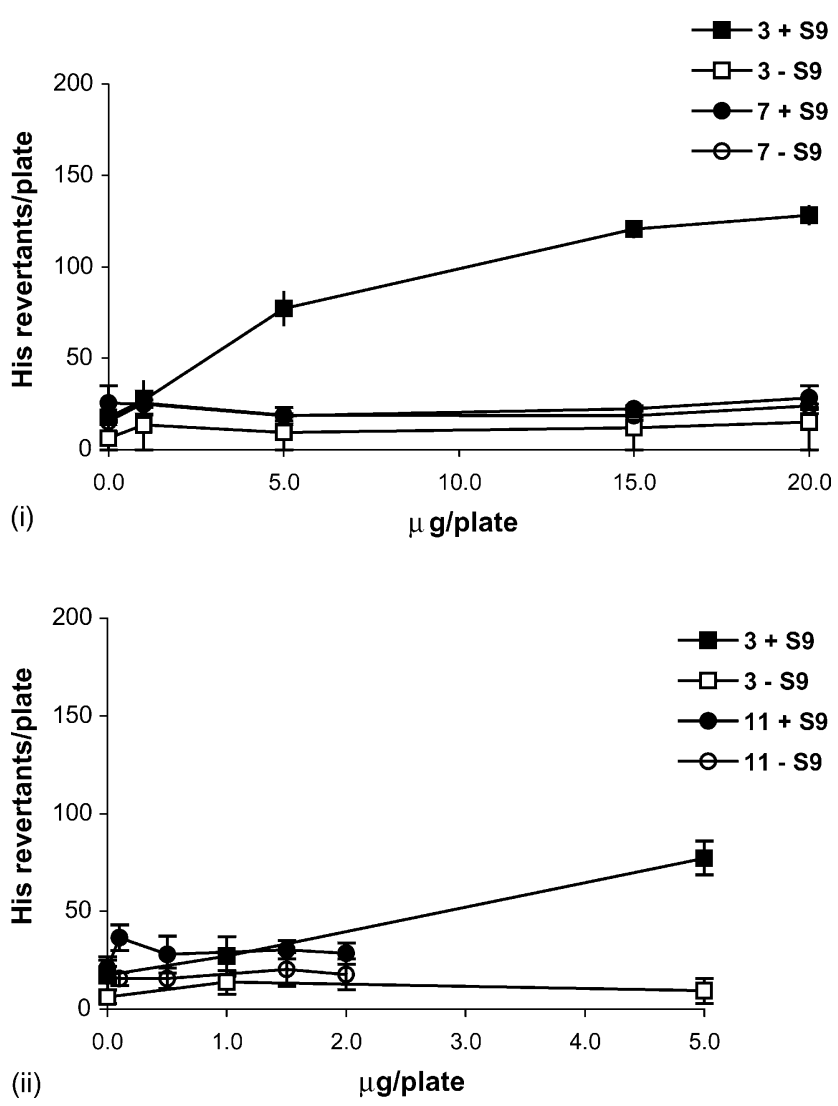

Fig. 4. Comparison of the dose-response curves of (i) aceanthrylene $(\mathbf{3},(\mathbf{\square})$ : $+\mathrm{S} 9$-mix $2 \%$, v/v, ( $\square$ ): $-\mathrm{S} 9$-mix) and its corresponding 1,2-

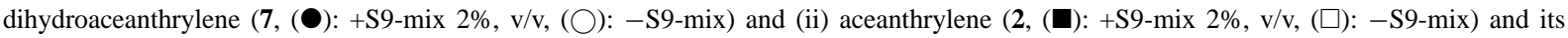
corresponding aceanthrylene-1,2-epoxide $(\mathbf{1 1},(\mathbf{O})$ : $+\mathrm{S} 9-\mathrm{mix} 2 \%, \mathrm{v} / \mathrm{v},(\bigcirc)$ : $-\mathrm{S} 9$-mix. (Note that in (ii), the concentration range is $0.0-2.0 \mu \mathrm{g} / \mathrm{plate}$ for 11, see text.) The standard protocol by Ames and coworkers [31,32] was followed using the S. typhimurium strain TA98.

mutagenic activity 61.8 and 61.0 His revertants/nmol, respectively, Table 1 ).

In Fig. 3, the mutagenic responses of 2 and its dihydro and epoxide derivatives $\mathbf{6}$ and 10, respectively, are presented. In this series, $\mathbf{2}$ does not show a mutagenic response both with and without S9-mix. In contrast, its dihydro derivative $\mathbf{6}$ exerts a weakly positive metabolism-dependent response (specific mutagenic activity of 1.1 His revertants/nmol). The epoxide 10 shows a positive response with S9-mix 2\% (v/v) and without S9-mix (specific mutagenic activity of 1.0 and 2.5 His revertants/nmol, respectively, Table 1).

Compound 3 exerts a positive specific mutagenic activity with S9-mix (2.4 His revertants/nmol, Fig. 4). Its dihydro derivative 7 is not mutagenic both with and without S9-mix. The epoxide derivative of 3, viz. 11 was tested as well. Unfortunately, its mutagenic response could not be determined due to the high toxicity observed. At the low dose range tested, a lack in the background lawn is observed and only small numbers of His (revertants) are scored. (See Appendix A: Table A.3).

In Fig. 5, the mutagenic activity of CP-PAH 4 and its corresponding dihydro $\mathbf{8}$ and epoxide $\mathbf{1 2}$ derivatives are shown. CP-PAH 4 exhibits a weak metabolismdependent specific mutagenic activity of 1.2 His revertants/nmol, and $\mathbf{8}$ is not mutagenic both with and without S9-mix. However, the epoxide 12 shows a high mutagenic response both in the presence and in the absence of S9-mix (specific mutagenic activity of 2.8 and 11.3 His revertants/nmol, respectively, Table 1). 

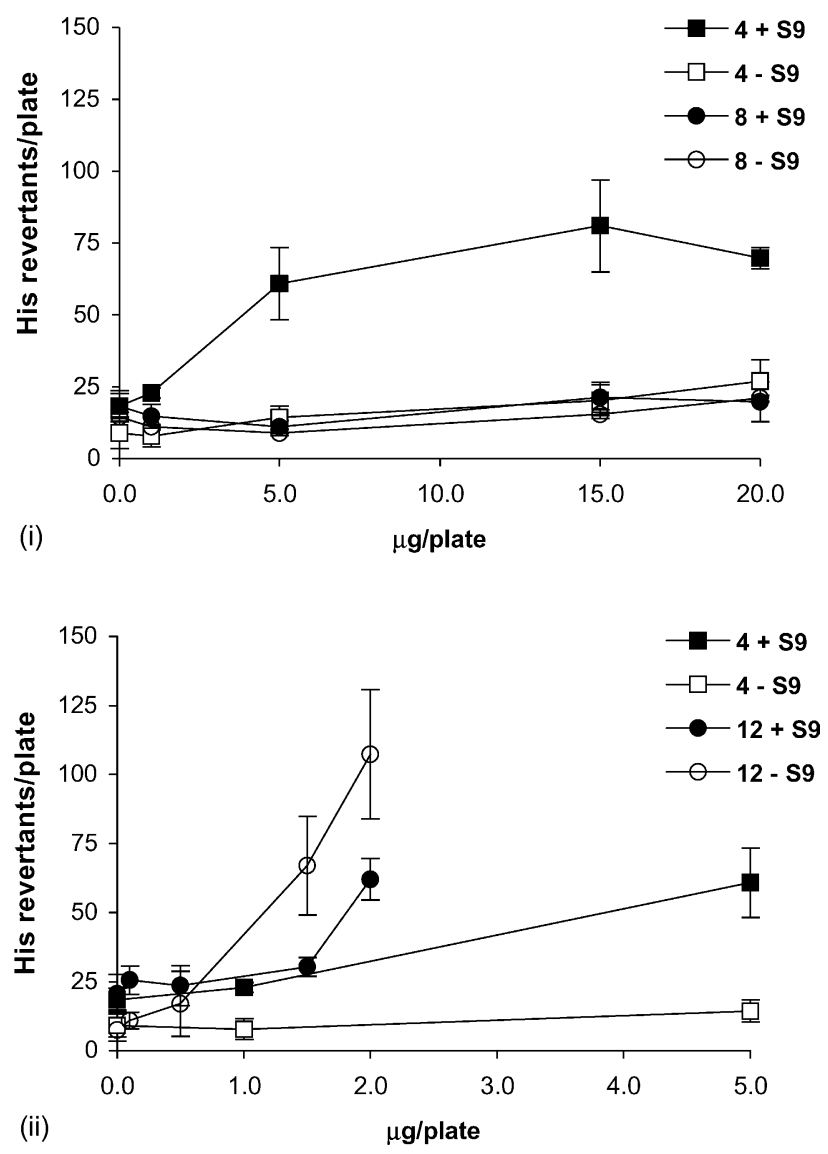

Fig. 5. Comparison of the dose-response curves of (i) cyclopenta[hi]chrysene (4, (ם): +S9-mix 2\%, v/v, ( $\square$ ): -S9-mix) and its corresponding 4,5-

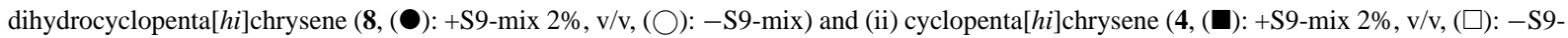
mix) and its corresponding cyclopenta[hi]chrysene-4,5-epoxide $(\mathbf{1 2},(\mathbf{O}):+\mathrm{S} 9-\mathrm{mix} 2 \%, \mathrm{v} / \mathrm{v},(\bigcirc)$ : $-\mathrm{S} 9$-mix. (Note that in (ii), the concentration range is $0.0-2.0 \mu \mathrm{g} / \mathrm{plate}$ for 12, see text.) The standard protocol by Ames and coworkers [31,32] was followed using the $S$. typhimurium strain TA98.

\section{Discussion}

\subsection{Mutagenicity assays}

Whereas CP-PAHs 1, 3 and 4 exhibit a positive metabolism-dependent bacterial mutagenic response in the Ames-assay ( $S$. typhimurium strain TA98, $\pm \mathrm{S} 9$ mix), compound 2 does not show mutagenic activity under similar conditions. The lack of mutagenic response determined for the dihydro-CP-PAHs $\mathbf{5}, \mathbf{7}$ and $\mathbf{8}$ indicates that the olefinic bond in the externally fused five-membered ring in $\mathbf{1}, \mathbf{3}$ and $\mathbf{4}$ represents the favourite site for bio-activation, i.e. epoxidation by the isoenzymes of cytochrome P450 in the S9-mix. Dihy- dro CP-PAH 6, however, was found to be moderately active with S9-mix under the experimental conditions applied. This suggests that another active site may be present in the phenanthrene-like core, since the parent CP-PAH 2 itself is not mutagenic (vide infra).

It is well established that for most CP-PAHs, the double bond at the cyclopenta moiety possesses olefinic character: it represents the most localized double bond according to both theoretical (ab initio calculations) [50-52] and experimental data (single crystal X-ray structures) $[53,54]$.

Thus, the epoxides 9-12 were synthesized, characterized (see Section 2.3) and subsequently assayed for their mutagenic response. Interestingly, the direct- 
Table A.2

Bacterial mutagenic activity ${ }^{\mathrm{a}}$ of 3,4-dihydrocyclopenta[ $c d$ ]pyrene (5), 3,4-dihydroacephenanthrylene (6), 1,2-dihydroaceanthrylene (7) and 4,5dihydrocyclopenta[hi]chrysene (8, Fig. 1) employing the Salmonella typhimurium strain TA98, with and without exogenous metabolic activation mixture $( \pm$ S9-mix)

\begin{tabular}{|c|c|c|c|c|c|c|c|c|}
\hline \multirow{2}{*}{$\begin{array}{l}\text { Concentration } \\
(\mu \mathrm{g} / \text { plate })\end{array}$} & \multicolumn{2}{|l|}{5} & \multicolumn{2}{|l|}{6} & \multicolumn{2}{|l|}{7} & \multicolumn{2}{|l|}{8} \\
\hline & $\begin{array}{l}+ \text { S9-mix } \\
2 \%(\mathrm{v} / \mathrm{v})\end{array}$ & -S9-mix & $\begin{array}{l}+ \text { S9-mix } \\
2 \%(\mathrm{v} / \mathrm{v})\end{array}$ & -S9-mix & $\begin{array}{l}+ \text { S9-mix } \\
2 \%(\mathrm{v} / \mathrm{v})\end{array}$ & -S9-mix & $\begin{array}{l}+ \text { S9-mix } \\
2 \%(\mathrm{v} / \mathrm{v})\end{array}$ & -S9-mix \\
\hline 0.0 & $25 \pm 2$ & $15.5 \pm 0.5$ & $14 \pm 2$ & $9 \pm 3$ & $25.5 \pm 9.5$ & $15.5 \pm 0.5$ & $18.3 \pm 5.5$ & $14.5 \pm 1.5$ \\
\hline 1.0 & $26.5 \pm 3.5$ & $16.5 \pm 0.5$ & $21.5 \pm 15$ & $10.5 \pm 2$ & $25 \pm 2$ & $25.5 \pm 6.5$ & $14.8 \pm 4.2$ & $11.0 \pm 1$ \\
\hline 5.0 & $41.5 \pm 7.5$ & $17.0 \pm 2$ & $71.5 \pm 8.5$ & $7 \pm 1$ & $18.5 \pm 4.5$ & $19 \pm 1$ & $11 \pm 2.3$ & $9 \pm 2$ \\
\hline 15.0 & $37 \pm 1$ & $18.0 \pm 2$ & $96 \pm 1$ & $18 \pm 3$ & $22.5 \pm 1.5$ & $18.5 \pm 2$ & $21.3 \pm 5.2$ & $15.5 \pm 3$ \\
\hline 20.0 & $65 \pm 2$ & $21.0 \pm 1$ & $71.5 \pm 4.5$ & $6.5 \pm 2.5$ & $28.5 \pm 6.5$ & $24 \pm 1$ & $19.8 \pm 7$ & $21 \pm 2$ \\
\hline $\begin{array}{l}\text { His revertants/ } \\
\mathrm{nmol}\left(r^{2}\right)\end{array}$ & $\sim 0.2\left(-^{\mathrm{b}}\right)$ & $\sim 0.2\left(-^{b}\right)$ & $1.1(0.99)$ & $\sim 0.1\left(\left(^{\mathrm{b}}\right)\right.$ & $0.2\left(-^{\mathrm{b}}\right)$ & $\sim 0.2\left(-^{\mathrm{b}}\right)$ & $\sim 0.2\left(\left(^{\mathrm{b}}\right)\right.$ & $\sim 0.2\left(\left(^{\mathrm{b}}\right)\right.$ \\
\hline
\end{tabular}

${ }^{a}$ Mutagenic response was determined as described in Section 2 [31,32]. Results shown are mean values \pm standard deviation (from triplicate plates for each dose in two independent experiments), and are given in His revertants per plate, without correction for spontaneous His revertants.

$\mathrm{b}$ The slope could not be determined.

acting mutagenic activity of $\mathbf{9}$ and $\mathbf{1 2}$ accounts for almost the entire metabolism-dependent mutagenic response of the parent CP-PAHs 1 and 4, respectively (Table 1). Unfortunately, epoxide $\mathbf{1 1}$ appears to be highly toxic to the bacteria, so that its mutagenic activity cannot be assessed. Interestingly, epoxide $\mathbf{1 0}$ is a direct-acting mutagen; whereas, its parent CP-PAH 2 shows no mutagenic activity upon metabolic activation. This suggests that $\mathbf{1 0}$ does not correspond to the ultimate mutagenic form of 2 .

Compound $\mathbf{1}$ is a highly active metabolismdependent bacterial mutagen (specific mutagenic ac- tivity 64.6 His revertants/nmol), and its ultimate, active mutagenic form is epoxide 9. This is confirmed in the present study. Whilst dihydro CP-PAH 5 exerts no mutagenic activity, epoxide 9 exhibits a high mutagenic response both with and without exogenous metabolic activation mixture (specific mutagenic activity 61.8 and $61.0 \mathrm{His}$ revertants/nmol). Since the direct-acting activity of $\mathbf{9}$ is similar to that exerted by its parent CP-PAH 1 in the presence of S9-mix, epoxidation at the cyclopenta moiety has to be considered as a metabolic activation pathway that is important for mutagenicity. Note, however, that metabolites

Table A.3

Bacterial mutagenic activity ${ }^{\mathrm{a}}$ of cyclopenta[ $\left.c d\right]$ pyrene-3,4-epoxide (9), acephenanthrylene-3,4-epoxide (10), aceanthrylene-1,2-epoxide (11) and cyclopenta[hi]chrysene-4,5-epoxide (12, Fig. 1) employing the Salmonella typhimurium strain TA98, with and without exogenous metabolic activation mixture $( \pm$ S9-mix $)$

\begin{tabular}{|c|c|c|c|c|c|c|c|c|}
\hline \multirow{2}{*}{$\begin{array}{l}\text { Concentration } \\
(\mu \mathrm{g} / \text { plate })\end{array}$} & \multicolumn{2}{|l|}{9} & \multicolumn{2}{|l|}{10} & \multicolumn{2}{|l|}{11} & \multicolumn{2}{|l|}{12} \\
\hline & $\begin{array}{l}+ \text { S9-mix } \\
2 \%(v / v)\end{array}$ & -S9-mix & $\begin{array}{l}+ \text { S9-mix } \\
2 \%(v / v)\end{array}$ & -S9-mix & $\begin{array}{l}+ \text { S9-mix } \\
2 \%(v / v)\end{array}$ & -S9-mix & $\begin{array}{l}+\mathrm{S} 9-\operatorname{mix} \\
2 \%(\mathrm{v} / \mathrm{v})\end{array}$ & -S9-mix \\
\hline 0.0 & $20.5 \pm 7.1$ & $7.5 \pm 2.6$ & $20.5 \pm 7.1$ & $7.5 \pm 2.6$ & $20.8 \pm 6^{\mathrm{b}}$ & $17.5 \pm 7.4^{b}$ & $20.5 \pm 7.1$ & $7.5 \pm 6.8$ \\
\hline 0.1 & $53.5 \pm 4.6$ & $38.3 \pm 10.9$ & $23.3 \pm 3.9$ & $18.8 \pm 6.2$ & $36.5 \pm 6.5^{\mathrm{b}}$ & $15.5 \pm 3.4^{\mathrm{b}}$ & $25.5 \pm 5.1$ & $10.8 \pm 4.2$ \\
\hline 0.5 & $164 \pm 35.5$ & $104.8 \pm 12.6$ & $23 \pm 6.1$ & $23 \pm 2.5$ & $28 \pm 9.4^{b}$ & $15.7 \pm 5.2^{b}$ & $23.5 \pm 7.2$ & $17 \pm 13.4$ \\
\hline 1.5 & $400 \pm 88.4$ & $499 \pm 45.0$ & $29.5 \pm 8.5$ & $31.5 \pm 7.4$ & $30.4 \pm 4.7^{b}$ & $20.3 \pm 8.6^{b}$ & $30.3 \pm 3.3$ & $67 \pm 17.9$ \\
\hline 2.0 & $476.7 \pm 96.5$ & $513.4 \pm 119.8$ & $30.8 \pm 3.7$ & $34.5 \pm 1.7$ & $28.5 \pm 5.5^{\mathrm{b}}$ & $17.8 \pm 7.9^{b}$ & $62 \pm 7.5$ & $107.3 \pm 23.4$ \\
\hline $\begin{array}{l}\text { His revertants/ } \\
\mathrm{nmol}\left(r^{2}\right)\end{array}$ & $61.8(0.98)$ & $61.0(0.93)$ & $1.0(0.95)$ & $2.5(0.90)$ & $-^{\mathrm{b}}$ & $-{ }^{b}$ & $2.8(0.50)$ & $11.3(0.95)$ \\
\hline
\end{tabular}

\footnotetext{
${ }^{a}$ Mutagenic response was determined as described in Section 2 [31,32]. Results shown are mean values \pm standard deviation (from triplicate plates for each dose in two independent experiments), and are given in His revertants per plate, without correction for spontaneous His revertants.

${ }^{\mathrm{b}}$ Lack of background lawn, toxicity was observed.
} 
derived from the epoxide, e.g. the related mono- and dihydroxy functionalized PAHs, can be activated by sulfonation. This requires an additional metabolic activation system that possesses sulfotransferase activity [17].

Acephenanthrylene (2) does not show any mutagenic activity both in the presence and in the absence of S9-mix. However, its epoxide $\mathbf{1 0}$ exhibits a directacting mutagenic response. This suggests that $\mathbf{2}$ cannot be properly metabolized by the cytochrome $\mathrm{P} 450$ isoenzymes in the S9-mix. Thus, our results show that 2 is biologically inactive, but that its corresponding epoxide $\mathbf{1 0}$ is considerable more active. Furthermore, the dihydro derivative $\mathbf{6}$ exhibits a weak specific mutagenic activity in the presence of S9-mix (1.1 His revertants/nmol), which may indicate that another site in the phenanthrene core is prone to undergo bio-activation. Further studies are required to resolve these observations.

Aceanthrylene (3) has been found to act as a highly potent mutagen [4,21]. In the present study, it is also found to be mutagenic but not as potent as was previously found [4], although the same $S$. typhimurium strain TA98 and an optimal microsome concentration in the S9-mix were employed in both investigations. Notwithstanding, the olefinic bond at the fivemembered ring is confirmed to be the site for epoxidation. The dihydro derivative of $\mathbf{3}$, viz. $\mathbf{7}$, is not mutagenic both in the presence or in the absence of S9mix. Under our conditions, the mutagenic potency of its epoxide 11 could not be determined due to the high cytotoxicity observed (lack of background lawn, see Appendix A (Tables A.1-A.3) for actual data). Nevertheless, epoxide $\mathbf{1 1}$ is proposed to be the ultimate, active mutagenic form of $\mathbf{3}$.

Cyclopenta[hi]chrysene (4) has been studied previously [5]. Note that $\mathbf{4}$, like $\mathbf{2}$, possesses both a cyclopenta moiety as well as a bay-region. In this investigation, both these possible bio-activation sites are studied by assaying $\mathbf{4}$ at low- and high protein content in the S9-mix (2 and 10\%, v/v), viz. 0.29 and $1.45 \mathrm{mg}$ protein/plate, respectively). With a high protein content, the formation of a diol-epoxide moiety at the bay-region is expected to become also operational, along with the formation of the arene-epoxide at the externally fused five-membered ring. In contrast to the data reported by Ball et al. [5] with 10\% (v/v) S9-mix, no increment in the number of revertants was found (data not shown). Hence, we propose that the main bioactivation pathway for $\mathbf{4}$ is epoxidation of the olefinic bond of the cyclopenta moiety, viz. by formation of epoxide 12. This is confirmed by the observation that its dihydro derivative $\mathbf{8}$ is not mutagenic both with and without S9-mix. Since a bay-region is still present in $\mathbf{8}$, this compound was also assayed for mutagenicity with S9-mix $10 \%(\mathrm{v} / \mathrm{v})$ to check if under these conditions exogenous metabolic activation via the diol-epoxide at the bay-region becomes operational. Also in this case, no positive mutagenic response was found (data not shown). Thus, activation via the formation of the diolepoxide in the bay-region for $\mathbf{4}$ is found to be marginal in the present study. Moreover, the epoxide $\mathbf{1 2}$ is found to exert a potent direct-acting mutagenic activity (specific mutagenic activity of 11.3 His revertants/nmol). In the presence of S9-mix, the mutagenic activity of $\mathbf{1 2}$ is reduced, which suggests that detoxification processes become operational.

\subsection{Semi-empirical AM1 calculations}

In this study, it is shown that epoxides $\mathbf{9}$ and $\mathbf{1 2}$ are the ultimate, active mutagenic forms of $\mathbf{1}$ and $\mathbf{4}$, respectively. The determination of the mutagenic potency of 11 is hindered due to the high cytotoxicity exerted under the experimental conditions applied. Notwithstanding, $\mathbf{1 1}$ is still proposed to be the ultimate, active mutagenic form of $\mathbf{3}$. Compound $\mathbf{1 0}$ exerts a direct-acting mutagenic activity, but its parent compound 2 is not mutagenic. Apparently, the enzymes present in the S9-mix cannot readily convert 2 into its epoxide $\mathbf{1 0}$. To rationalize the differences in mutagenic response exerted by the CP-PAHs 1-4 and their corresponding ultimate, active mutagenic forms, i.e. the epoxides 9-12, the heats of formation $\left(\Delta H_{\mathrm{f}}^{\circ}\right.$ in $\mathrm{kcal} / \mathrm{mol}$, Table 2$)$ of 1-4, 9-12 and the corresponding monohydroxy-carbocations $9 \mathbf{a}-12 a$ or 9b-12b derived from epoxide-ring opening (Fig. 1) were computed using the semi-empirical AM1 method [30] (see Section 2.4). It has been proposed previously

Fig. 6. Heats of formation $\left(\Delta H_{\mathrm{f}}^{\circ}\right.$ in $\left.\mathrm{kcal} / \mathrm{mol}\right)$ and heats of reaction $(\Delta E$ in $\mathrm{kcal} / \mathrm{mol})$ for bay-region epoxidation of 2 and 4 in their PAH core calculated using the semi-empirical AM1 method [30] (see Section 2.4). 


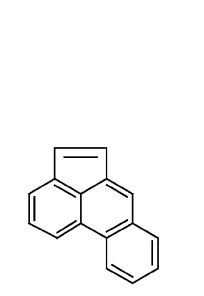

2, $\Delta \mathrm{H}_{\mathrm{f}}^{\circ}=95.9$

$\stackrel{\Delta \mathrm{E}=2.0}{\longrightarrow}$

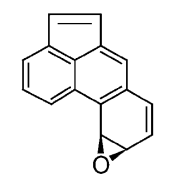

13, $\Delta \mathrm{H}_{\mathrm{f}}^{\circ}=97.9$
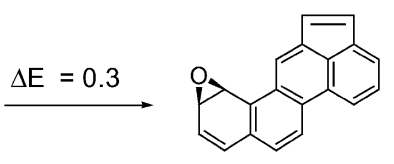

15a, $\Delta H_{f}^{\circ}=114.9$

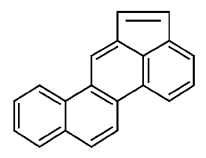

4, $\Delta \mathrm{H}_{\mathrm{f}}^{\mathrm{O}}=115.2$

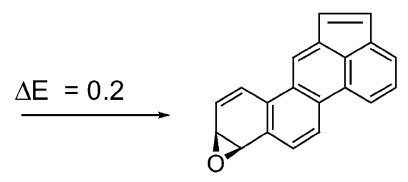

15b, $\Delta \mathrm{H}_{\mathrm{f}}^{\mathrm{O}}=115.4$

$\stackrel{\Delta \mathrm{E}=134.9}{\longrightarrow}$

$\Delta \mathrm{E}=136.8$

$\Delta \mathrm{E}=137.9$

$\Delta \mathrm{E}=137.6$

$\longrightarrow$

$\Delta \mathrm{E}=-3.1$

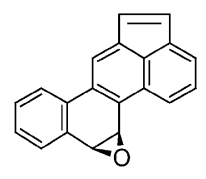

$\Delta \mathrm{E}=134.7$

15c, $\Delta H^{\circ}=112.1 \quad \Delta E=139.2$

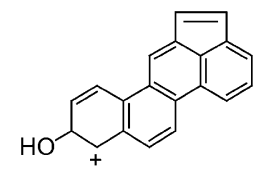

$17 a, \Delta H_{f}^{\circ}=252.2$

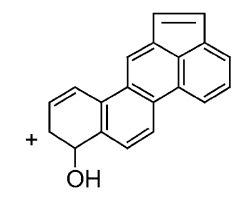

$17 b, \Delta H_{f}^{\circ}=250.3$

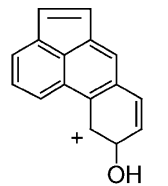

14a, $\Delta \mathrm{H}_{\mathrm{f}}^{\circ}=234.7$

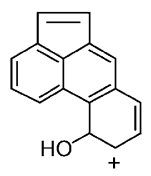

14b, $\Delta H_{f}^{\circ}=236.0$

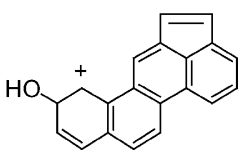

16a, $\Delta \mathrm{H}_{\mathrm{f}}^{\circ}=252.8$

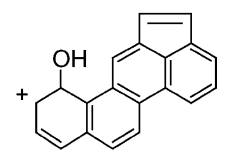

16b, $\Delta \mathrm{H}_{\mathrm{f}}^{\circ}=252.5$

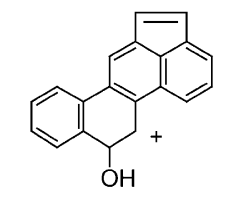

18a, $\Delta \mathrm{H}_{\mathrm{f}}^{\circ}=246.8$

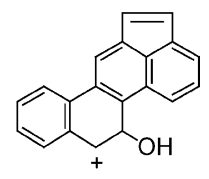

18b, $\Delta \mathrm{H}_{\mathrm{f}}^{\circ}=251.3$ 
that the most stable monohydroxy-carbocation may react with DNA and can induce mutation [12].

The energy difference $(\Delta E$ in $\mathrm{kcal} / \mathrm{mol})$ between CP-PAHs 1-4 and their epoxides 9-12 gives a qualitative estimate of the ease of epoxidation at the cyclopenta moiety. For all CP-PAHs 1-4, the ease of epoxidation is nearly the same $(\sim 18 \mathrm{kcal} / \mathrm{mol}$, Table 2$)$. However, for the next step, viz. epoxide-ring opening into the two possible monohydroxy-carbocations, differences are found. From epoxides 9 to 12, the most stable monohydroxy-carbocation will be the isomer with its positive charge located at a 'benzyliclike' position (9a-10a). For 9 and 11, the considerable energy difference between the two monohydroxycarbocations $(\Delta E$ in $\mathrm{kcal} / \mathrm{mol})$ indicates that the most stable species 9a $(\Delta E(\mathbf{9 a}-9 \mathbf{b}),-6.4 \mathrm{kcal} / \mathrm{mol})$ and $11 \mathbf{a}$ $(\triangle E(\mathbf{1 1 a}-11 \mathrm{~b})-8.5 \mathrm{kcal} / \mathrm{mol}$, Fig. 1 and Table 2) will be predominantly formed. However, for $\mathbf{1 0}$ and $\mathbf{1 2}$ both monohydroxy-carbocations 10a-10b and 12a-12b, respectively, possess similar $\Delta H_{\mathrm{f}}^{\circ}$ values. This indicates that both monohydroxy-carbocations are of similar stability $(\Delta E(\mathbf{1 0 a}-\mathbf{1 0 b})-0.7 \mathrm{kcal} / \mathrm{mol}$ and $\Delta E$ $(\mathbf{1 2 a}-12 b)-2.9 \mathrm{kcal} / \mathrm{mol}$, Fig. 1 and Table 2). Consequently, these results suggest that the carbocation intermediates 10a and 10b, and 12a and $\mathbf{1 2 b}$, respectively, will coexist. The GC trace from the GC/MS spectrum of $\mathbf{1 0}$ and $\mathbf{1 2}$ corroborates these observations, since two products derived from the thermal rearrangement of the epoxide into the two possible ketones are detected. In contrast, for $\mathbf{9}$ and $\mathbf{1 1}$ only one product is found (see Section 2.3). When the $\Delta E$ values for the conversion of the epoxides 9-12 into their most stable monohydroxycarbocations (9a-12a) are compared, the order for the ease of epoxide-ring opening is $\mathbf{1 1}>\mathbf{9}>\mathbf{1 2}>\mathbf{1 0}$. This is the same order as found for the direct-acting mutagenic activity of the epoxides 9-12, with the exception of 11, which was found to be highly cytotoxic.

As discussed in the Section 1, for PAHs exerting a positive bacterial mutagenic response the presence of a bay-region has been postulated as a prerequisite [12] to exert bioactivity. Intriguingly, most CP-PAHs that exhibit bacterial mutagenic activity lack this structural feature. Accordingly, their mutagenic potency is rationalized by invoking epoxidation of the olefinic bond in the annelated cyclopenta moiety. CP-PAHs such as 2 and 4 (Fig. 1), however, possess besides a cyclopenta moiety, also a bay-region in their central PAH core, i.e. both structural features are present. This raises the question which of the two sites in $\mathbf{2}$ and $\mathbf{4}$ is more susceptible to undergo epoxidation. To gain insight into this question, the heats of formation $\left(\Delta H_{\mathrm{f}}^{\circ}\right.$ in $\left.\mathrm{kcal} / \mathrm{mol}\right)$ of the possible bay-region epoxides of $\mathbf{2}$ and $\mathbf{4}$, viz. 13 and 15a-c, respectively, were calculated using the semi-empirical AM1 method (Fig. 6). A comparison of the energy difference ( $\Delta E$ in $\mathrm{kcal} / \mathrm{mol}$ ) between the parent CP-PAHs 2 and $\mathbf{4}$ and their related epoxides at the olefinic bond (10 and 12, respectively) as well as at the bay-region positions (13 and $\mathbf{1 5 a}-\mathbf{c}$, respectively) shows that epoxidation at the olefinic bond of the cyclopenta moiety is considerably more facile. In contrast, the energy differences $(\Delta E$ in $\mathrm{kcal} / \mathrm{mol})$ computed for epoxide-ring opening at the olefinic bond and at the bay-region positions into the possible monohydroxylcarbocations (14a-b, 16a-b, 17a-b and 18a-b, respectively) are similar (Fig. 6). Hence, the semi-empirical AM1 results qualitatively support our experimental observation that in the case of a CP-PAH, epoxidation at the olefinic bond is favoured and responsible for their bacterial mutagenic response.

\section{Conclusions}

The results of this study are consistent with the postulated role of the epoxides at the cyclopenta moiety as the ultimate, active mutagenic metabolites from CP-PAHs; they are direct-acting mutagens (-S9-mix) in the standard Ames-assay. The importance of the olefinic bond of the five-membered ring of CP-PAHs to exert positive mutagenic activity is demonstrated by assaying the mutagenic response of the partially hydrogenated dihydro-CP-PAHs. Since no mutagenic response was observed for the latter, this correlates with the fact that the double bond at the externally fused fivemembered ring is the favourable site for metabolic activation (epoxidation) by the $\mathrm{P} 450$ isoenzymes present in the S9-mix. This is confirmed by the direct-acting mutagenicity of the epoxides 9-12. It should be noted that metabolites derived from the epoxide, e.g. via epoxide-ring opening to the related mono- and dihydroxy functionalized PAHs, can also be activated by sulfonation if sulfotransferase activity in the activation medium is available $[16,17]$. The experimental results are supported by semi-empirical AM1 calculations on the epoxides 9-12 and their corresponding monohydroxy-carbocations 9a-12a and 9b-12b ob- 
tained by epoxide-ring opening. In addition, for $\mathrm{CP}$ PAHs 2 and $\mathbf{4}$, which also possess a bay-region besides the annelated cyclopenta moiety, semi-empirical AM1 calculations show that, in line with our experimental observations, epoxidation at the olefinic bond of the cyclopenta moiety is favoured.

\section{Acknowledgements}

Financial support from the Eusko JaurlaritzaGobierno Vasco, 'Beca para Formación de Investigadores' (M.J. Otero-Lobato), the Netherlands Organisation for Scientific Research (NWO) Grant 700.53.401 (R.W.A. Havenith), as well as technical support from Dr. A.Y. Simarro and S.M. Nijmeijer (Veterinary Pharmacology, Pharmacy and Toxicology, Utrecht University, The Netherlands) are gratefully acknowledged.

\section{Appendix A}

Analytical and spectral data of compounds 5-12.

\section{A.1. 3,4-Dihydrocyclopenta[cd]pyrene (5)}

Mp $133-134{ }^{\circ} \mathrm{C} . \delta_{\mathrm{H}}\left(\mathrm{CDCl}_{3}\right): 8.12(1 \mathrm{H}, \mathrm{d}, J 8.0)$, 8.06-8.00 (3H, m), 7.95 (1H, d, J 7.7), $7.93(1 \mathrm{H}, \mathrm{d}, J$ 7.7), $7.90(1 \mathrm{H}, \mathrm{t}, J 7.7), 7.78(1 \mathrm{H}, \mathrm{m}), 3.70-3.66(2 \mathrm{H}$, $\mathrm{m})$ and $3.62-3.58(2 \mathrm{H}, \mathrm{m}) . \delta_{\mathrm{C}}\left(\mathrm{CDCl}_{3}\right): 144.9,142.1$, 136.6, 133.6, 131.3, 128.3, $126.9(\mathrm{C}-\mathrm{H}), 126.2(\mathrm{C}-\mathrm{H})$, $126.1(\mathrm{C}-\mathrm{H}), 124.9(\mathrm{C}-\mathrm{H}), 123.9(\mathrm{C}-\mathrm{H}), 123.8,122.8$ $(\mathrm{C}-\mathrm{H}), 122.4,121.6(\mathrm{C}-\mathrm{H}), 118.6(\mathrm{C}-\mathrm{H}), 30.9\left(\mathrm{CH}_{2}\right)$ and $30.5\left(\mathrm{CH}_{2}\right)$ (see also [43]).

\section{A.2. 4,5-Dihydroacephenanthrylene (6)}

Mp 106-107 ${ }^{\circ} \mathrm{C} . \delta_{\mathrm{H}}\left(\mathrm{CDCl}_{3}\right): 8.61-8.58(1 \mathrm{H}, \mathrm{m})$, $8.33(1 \mathrm{H}, \mathrm{d}, J$ 8.1), 7.87-7.84 (1H, m), 7.62-7.52 (4H, $\mathrm{m}), 7.48(1 \mathrm{H}, \mathrm{d}, J 7.8)$ and $3.44(4 \mathrm{H}, \mathrm{s}) . \delta_{\mathrm{C}}\left(\mathrm{CDCl}_{3}\right)$ : 145.5, 143.9, 137.8, 134.3, 128.6, 128.5, $128.4(\mathrm{C}-\mathrm{H})$, $128.0(\mathrm{C}-\mathrm{H}), 126.4(\mathrm{C}-\mathrm{H}), 125.0(\mathrm{C}-\mathrm{H}), 122.8$ $(\mathrm{C}-\mathrm{H}), 121.2(\mathrm{C}-\mathrm{H}), 119.0(\mathrm{C}-\mathrm{H}), 118.8(\mathrm{C}-\mathrm{H}), 30.5$ $\left(\mathrm{CH}_{2}\right)$ and $29.4\left(\mathrm{CH}_{2}\right)$. (see also $\left.[44,45]\right)$.

\section{A.3. 1,2-Dihydroaceanthrylene (7)}

$\mathrm{Mp} \quad 112-113^{\circ} \mathrm{C} . \quad \delta_{\mathrm{H}} \quad\left(\mathrm{CDCl}_{3}\right): 8.19 \quad(1 \mathrm{H}, \quad$ bs $)$, 8.07-8.04 (1H, m), 8.01-7.98 (1H, m), $7.74(1 \mathrm{H}, \mathrm{d}, J$
8.8), 7.48-7.41 (3H, m), 7.24 (1H, d, J 6.6), 3.80-3.76 $(2 \mathrm{H}, \mathrm{m})$ and $3.59-3.55(2 \mathrm{H}, \mathrm{m}) . \delta_{\mathrm{C}}\left(\mathrm{CDCl}_{3}\right): 147.1$, 142.6, 137.4, 133.7, 129.8, $129.4(\mathrm{C}-\mathrm{H}), 127.7(\mathrm{C}-\mathrm{H})$, 127.1, $125.1(\mathrm{C}-\mathrm{H}), 124.7(\mathrm{C}-\mathrm{H}), 124.5(\mathrm{C}-\mathrm{H}), 122.2$ $(\mathrm{C}-\mathrm{H}), 121.3(\mathrm{C}-\mathrm{H}), 117.2(\mathrm{C}-\mathrm{H}), 30.5\left(\mathrm{CH}_{2}\right)$ and $29.6\left(\mathrm{CH}_{2}\right)$ (see also $\left.[44,46]\right)$.

\section{A.4. 4,5-Dihydrocyclopenta[hi]chrysene (8)}

Mp $185-186^{\circ} \mathrm{C} . \delta_{\mathrm{H}}\left(\mathrm{CDCl}_{3}\right): 8.80(1 \mathrm{H}, \mathrm{d}, J 8.3)$, $8.63(1 \mathrm{H}, \mathrm{d}, J 8.8), 8.54(1 \mathrm{H}, \mathrm{s}), 8.40(1 \mathrm{H}, \mathrm{d}, J 8.3)$, $7.99(1 \mathrm{H}, \mathrm{d}, J 8.0), 7.94(1 \mathrm{H}, \mathrm{d}, J 8.8), 7.70-7.58$ $(3 \mathrm{H}, \mathrm{m}), 7.48(1 \mathrm{H}, \mathrm{d}, J 6.6)$ and $3.59-3.50(4 \mathrm{H}$, m). $\delta_{\mathrm{C}}\left(\mathrm{CDCl}_{3}\right) 145.9,144.8,132.5,130.8,130.4$, 129.0, $128.6(\mathrm{C}-\mathrm{H}), 128.3(\mathrm{C}-\mathrm{H}), 127.0(\mathrm{C}-\mathrm{H})$, $126.2(\mathrm{C}-\mathrm{H}), 126.0(\mathrm{C}-\mathrm{H}), 125.7,123.3(\mathrm{C}-\mathrm{H})$, $121.4(\mathrm{C}-\mathrm{H}), 120.7(\mathrm{C}-\mathrm{H}), 119.1(\mathrm{C}-\mathrm{H}), 115.2,113.9$ $(\mathrm{C}-\mathrm{H}), 30.2\left(\mathrm{CH}_{2}\right)$ and $29.2\left(\mathrm{CH}_{2}\right)$. GC/MS: $\mathrm{m} / \mathrm{z}(\mathrm{MS})$ $254\left(M^{\bullet+},(100), 226(10), 126\right.$ (42), 113 (22).

\section{A.5. Cyclopenta[cd]pyrene-3,4-epoxide (9)}

$\delta_{\mathrm{H}}\left(\mathrm{d}_{6}\right.$-Acetone): $8.39(1 \mathrm{H}, \mathrm{d}, J 7.8), 8.35(1 \mathrm{H}, \mathrm{s})$, $8.31(1 \mathrm{H}, \mathrm{dd}, J 7.7, J 1.1), 8.22(2 \mathrm{H}$, AB system, $J$ 7.7), $8.15(2 \mathrm{H}, \mathrm{s}), 8.08(1 \mathrm{H}, \mathrm{t}, J 7.7), 5.19$ ( $2 \mathrm{H}, \mathrm{AB}$ system, $J 2.5) ; \delta_{\mathrm{C}}\left(\mathrm{d}_{6}\right.$-acetone): 138.4, 136.4, 136.2, 132.1, 131.0, 130.7, 128.5, $128.1(\mathrm{C}-\mathrm{H}), 127.1(\mathrm{C}-\mathrm{H}), 127.0$ $(\mathrm{C}-\mathrm{H}), 126.6(\mathrm{C}-\mathrm{H}), 125.8(\mathrm{C}-\mathrm{H}), 124.4(\mathrm{C}-\mathrm{H})$, $123.9(\mathrm{C}-\mathrm{H}), 123.2(\mathrm{C}-\mathrm{H}), 122.7,59.2(\mathrm{C}-\mathrm{H})$ and 58.7 (C-H). GC/MS: $\mathrm{m} / \mathrm{z}$ (relative intensity) $242\left(\mathrm{M}^{\bullet+}, 80\right)$, 214 (100), 187 (12) 107 (30). Under GC/MS conditions, 9 rearranges to 3,4-dihydrocyclopenta[ $c d]$ pyren4-one [49].

\section{A.6. Acephenanthrylene-4,5-epoxide (10)}

$\delta_{\mathrm{H}}\left(\mathrm{d}_{6}\right.$-Acetone): $8.72(1 \mathrm{H}, \mathrm{dd}, J 6.0), 8.56(1 \mathrm{H}$, $\mathrm{d}, J$ 8.3), $8.06(1 \mathrm{H}, \mathrm{d}, J 7.7), 8.03(1 \mathrm{H}, \mathrm{s}), 7.82(1 \mathrm{H}$, $\mathrm{d}, J$ 6.9), 7.73-7.63 $(3 \mathrm{H}, \mathrm{m}), 4.97(2 \mathrm{H}, \mathrm{AB}$ system, $\left.\delta_{\mathrm{A}} 4.98 \delta_{\mathrm{B}} 4.96, J_{\mathrm{AB}} 2.5\right) . \delta_{\mathrm{C}}\left(\mathrm{d}_{6}\right.$-Acetone): 141.1, $138.8,138.4,134.9,131.5,131.2(\mathrm{C}-\mathrm{H}), 130.6,129.4$ $(\mathrm{C}-\mathrm{H}), 128.7(\mathrm{C}-\mathrm{H}), 128.6(\mathrm{C}-\mathrm{H}), 125.5(\mathrm{C}-\mathrm{H})$, $124.9(\mathrm{C}-\mathrm{H}), 124.6(\mathrm{C}-\mathrm{H}), 123.6(\mathrm{C}-\mathrm{H}), 59.8(\mathrm{C}-\mathrm{H})$ and $59.1(\mathrm{C}-\mathrm{H})$. GC/MS: $\mathrm{m} / \mathrm{z}$ (relative intensity) two distinct peaks are discernible in the GC trace: I, (45\%): $218\left(M^{\bullet+}, 100\right), 202$ (11), 189 (90), 94 (20) and II, (55\%): $218\left(M^{\bullet+}, 100\right), 202$ (16), 189 (86), 95 (27). Under GC/MS conditions, 10 rearranges into the two 
isomeric ketones, viz. 4,5-dihydro-acephenanthrylen4-one and 4,5-dihydro-acephenanthylen-5-one are observed in the spectrum (see also [49]).

\section{A.7. Aceanthrylene-1,2-epoxide (11)}

$\delta_{\mathrm{H}}\left(\mathrm{d}_{6}\right.$-Acetone): $8.48(1 \mathrm{H}, \mathrm{s}), 8.43(1 \mathrm{H}, \mathrm{d}, J 7.7)$, $8.17(1 \mathrm{H}, \mathrm{d}, J 8.5), 7.99(1 \mathrm{H}, \mathrm{d}, J 8.8), 7.73(1 \mathrm{H}, \mathrm{d}$, $J$ 6.3), 7.65-7.47 (3H, m), $7.55(2 \mathrm{H}, \mathrm{m}), 5.55(1 \mathrm{H}$, $\mathrm{d}, J 2.5), 5.12(1 \mathrm{H}, \mathrm{d}, J 2.5) . \delta_{\mathrm{C}}\left(\mathrm{d}_{6}\right.$-Acetone): 140.7 , $137.3,136.5,135.1,134.3,130.5(\mathrm{C}-\mathrm{H}), 130.4,127.8$ $(\mathrm{C}-\mathrm{H}), 127.4(\mathrm{C}-\mathrm{H}), 126.9(\mathrm{C}-\mathrm{H}), 126.3(\mathrm{C}-\mathrm{H})$, $125.9(\mathrm{C}-\mathrm{H}), 124.5(\mathrm{C}-\mathrm{H}), 123.0(\mathrm{C}-\mathrm{H}), 58.8(\mathrm{C}-\mathrm{H})$ and $57.3(\mathrm{C}-\mathrm{H})$. GC/MS $\mathrm{m} / \mathrm{z}$ (relative intensity): 218 $\left(M^{\bullet+}, 100\right), 202$ (5), 190 (75), 189 (95), 163 (15), 95 (21), 94 (22). Under the GC/MS conditions, 11 rearranges into 1,2-dihydro-aceanthrylen-2-one (see also $[44,49])$.

\section{A.8. Cyclopenta[hi]chrysene-4,5-epoxide (12)}

$\delta_{\mathrm{H}}\left(\mathrm{d}_{6}\right.$-Acetone): $9.13(1 \mathrm{H}, \mathrm{s}), 8.99(1 \mathrm{H}, \mathrm{d}, J 8.5)$, $8.78(1 \mathrm{H}, \mathrm{d}, J 9.1), 8.68(1 \mathrm{H}, \mathrm{d}, J 8.3), 8.16(2 \mathrm{H}, \mathrm{m})$, $7.85(1 \mathrm{H}, \mathrm{d}, J 6.9), 7.80-7.67(3 \mathrm{H}, \mathrm{m}), 5.12(1 \mathrm{H}, \mathrm{d}, J$ 2.5), $5.05(1 \mathrm{H}, \mathrm{d}, J 2.5) . \delta_{\mathrm{C}}\left(\mathrm{d}_{6}\right.$-Acetone $): 140.5,138.9$, 137.7, 133.5 (C-H), 132.1, 130.2, 130.0, $129.6(\mathrm{C}-\mathrm{H})$, $128.8(\mathrm{C}-\mathrm{H}), 128.7(\mathrm{C}-\mathrm{H}), 127.9(\mathrm{C}-\mathrm{H}), 127.5$ $(\mathrm{C}-\mathrm{H}), 124.3(\mathrm{C}-\mathrm{H}), 124.1(\mathrm{C}-\mathrm{H}), 123.3(\mathrm{C}-\mathrm{H})$, $122.1(\mathrm{C}-\mathrm{H}), 119.3,119.2,59.1(\mathrm{C}-\mathrm{H}), 58.8(\mathrm{C}-\mathrm{H})$. GC/MS $m / z$ (relative intensity) two distinct peaks are discernible in the GC trace: I, 75\%: $268\left(M^{\bullet+} 97\right), 239$ (100), 219 (57), 119 (40), 87 (30) and II, $25 \%, 268$ $\left(M^{\bullet+} 97\right), 239$ (100), $219(13), 119$ (25). Under GC/MS conditions, 12 rearranges into the isomeric ketones, viz. 4,5-dihydro-cyclopenta[hi]chrysen-4-one and 4,5dihydro-cyclopenta[hi]chrysen-5-one.

\section{References}

[1] U.E. Wiersum, L.W. Jenneskens, The Formation of polyaromatic hydrocarbons, fullerenes and soot in combustion: pyrolytic mechanisms and the industrial and environmental connection, in: Y. Vallée (Ed.), Gas Phase Reactions in Organic Synthesis, Gordon and Breach Science Publishers, New York, 1997, pp. 143-194.

[2] A.M. Mastral, M.S. Callén, T. García, Toxic organic emissions from coal combustion, Fuel Process. Technol. 67 (2000) 1-10.
[3] E. Eisenstadt, A. Gold, Cyclopenta[cd]pyrene: a highly mutagenic PAH, Proc. Nat. Acad. Sci. U.S.A. 75 (1978) 1667-1669.

[4] M.J. Kohan, R. Sangaiah, L.M. Ball, A. Gold, Bacterial mutagenicity of aceanthrylene: a novel CP-PAH of low molecular weight, Mutat. Res. 155 (1985) 95-98.

[5] L.M. Ball, S.H. Warren, R. Sangaiah, S. Nesnow, A. Gold, Bacterial mutagenicity of new cyclopenta-fused cataannelated PAH, and identification of the major metabolites of benz $[j]$ acephenanthrylene formed by aroclor-treated rat liver microsomes, Mutat. Res. 224 (1989) 115-125.

[6] A. Gold, S. Nesnow, M. Moore, H. Garland, G. Curtis, B. Howard, D. Graham, E. Eisenstadt, Mutagenesis, Morphological transformation of mammalian cells by a non-bay-region polycyclic cyclopenta[ $[c d]$ pyrene and its 3,4-oxide, Cancer Res. 40 (1980) 4482-4484.

[7] A.L. Lafleur, J.P. Longwell, J.A. Marr, P.A. Monchamp, E.F. Plummer, W.G. Thilly, P.P.Y. Mulder, B.B. Boere, J. Cornelisse, J. Lugtenburg, Bacterial and human cell mutagenicity study of some $\mathrm{C}_{18} \mathrm{H}_{10}$ cyclopenta-fused $\mathrm{PAH}$ associated with fossil fuels combustion, Environ. Health Perspect. 101 (1993) 146-153.

[8] J.L. Durant, W.F.J. Busby, A.L. Lafleur, B.W. Penman, C.L. Crespi, Human cell mutagenicity of oxygenated, nitrated and unsubstituted PAH associated with urban aerosols, Mutat. Res. 371 (1996) 123-157.

[9] A.W. Wood, W. Levin, R.L. Chang, M. Huang, D. Ryan, P.E. Thomas, R. Lehr, S. Kumar, M. Koreeda, H. Akagi, Y. Ittah, P. Dansette, H. Yagi, D.M. Jerina, A.H. Conney, Mutagenicity and tumor-initiating activity cyclopenta[cd]pyrene and structurally related compounds, Cancer Res. 40 (1980) 642-649.

[10] E. Cavalieri, E. Rogan, B. Toth, A. Munhall, Carcinogenicity of the environmental pollutants cyclopenteno $[c d]$ pyrene and cyclopentano $[c d]$ pyrene in mouse skin, Carcinogenesis 2 (1981) 227-281.

[11] E. Cavalieri, A. Munhall, E. Rogan, S. Salmasi, K. Patil, Syncarcinogenic effect of the environmental pollutants cyclopenteno $[c d]$ pyrene and benzo $[a]$ pyrene in mouse skin, Carcinogenesis 4 (1983) 393-397.

[12] D.M. Jerina, R.E. Lehr, H. Yagi, O. Hernandez, P.M. Dansette, P.G. Wislocki, A.W. Wood, R.L. Chang, W. Levin, A.H. Conney, Mutagenicity of $\mathrm{B}[a] \mathrm{P}$ derivatives and the description of a quantum mechanical model which predicts the use of carbonium ion formation from diol-epoxides, in: F.J. deSerres, J.R. Fouts, J.R. Bend, R.M. Philpot (Eds.), In Vitro Metabolic Activation in Mutagenesis Testing, Elsevier/North Holland Biomedical Press, Amsterdam, 1976, pp. 159-177.

[13] K.O. Newcomb, R. Sangaiah, A. Gold, L.M. Ball, Activation and metabolism of benz[j] aceanthrylenene-9,10-dihydrodiol, the precursor to 'bay-region' metabolism of the genotoxic CPPAH benz[j]aceanthrylene, Mutat. Res. 287 (1993) 181-190.

[14] L.M. Ball, S.H. Warren, R. Sangaiah, A. Gold, Bacterial mutagenicity of two cyclopentafused isomers of benzpyrene, Mutat. Res. 260 (1991) 271-279.

[15] A. Gold, J. Brewster, E. Eisenstadt, Synthesis of cyclopenta $[c d]$ pyrene-3,4-epoxide, the ultimate mutagenic metabolite of the environmental carcinogen, cyclopenta $[c d]$ pyrene, J. Chem. Soc., Chem. Commun. (1979) 902-903. 
[16] Y.-J. Surh, H. Kwon, S.R. Tannenbaum, Sulfotransferasemediated activation of 4-hydroxy- and 3,4-dihydroxy3,4-dihydrocyclopenta[ $c d]$ pyrene, major metabolites of cyclopenta[cd]pyrene, Cancer Res. 53 (1993) 1017-1022.

[17] Y.-J. Surh, Bioactivation of benzylic and allylic alcohols via sulfo-conjugation, Chem. Biol. Interact. 109 (1998) 221-235.

[18] A.C. Beach, S.K. Agarwal, G.R. Lambert, S. Nesnow, R.C. Gupta, Reaction of CPP-epoxide with DNA and deoxynucleotides, Carcinogenesis 14 (1993) 767-771.

[19] A.C. Beach, R.C. Gupta, DNA adducts of the ubiquitous environmental contaminant cyclopenta $[c d]$ pyrene, Carcinogenesis 15 (1994) 1065-1072.

[20] C.-H. Hsu, P.L. Skipper, T.M. Harris, S.R. Tannenbaum, Characterization of DNA Adducts formed by cyclopenta[ $[c d]$ pyrene epoxide, Chem. Res. Toxicol. 10 (1997) 248-253.

[21] R. Sangaiah, A. Gold, L.M. Ball, D.L. Matthews, G.E. Toney, Synthesis and resolution of putative diastereomeric $\mathrm{N}^{2}$-deoxyguanosine and $\mathrm{N}^{2}$-deoxyadenosine adducts of biologically active cyclopenta PAH, Tetrahedron Lett. 33 (1992) 5487-5490.

[22] S. Nesnow, J. Ross, N. Mohapatra, R. Gupta, R. Sangaiah, A. Gold, Genotoxicity and identification of the major DNAadducts of aceanthrylene, in: M. Cooke, K. Loening, J. Merritt (Eds.), Polynuclear Aromatic Hydrocarbons: Measurements, Means, and Metabolism. Eleventh International Symposium, Columbus, Ohio, Battelle Press, 1991, pp. 629-639.

[23] M.J. Otero-Lobato, L.W. Jenneskens, W. Seinen, Bacterial Mutagenicity of dicyclopenta-fused pyrene congeners in FVTpyrolysates: partial combustion exhaust mimics, Polycycl. Aromat. Compd. 24 (2004) 567-582.

[24] W.F. Busby Jr., H. Smith, E.F. Plummer, A.L. Lafleur, P.P.Y. Mulder, B.B. Boere, J. Cornelisse, J. Lugtenburg, Mutagenicity of cyclopenta-Fused polynuclear aromatic hydrocarbons and a non-polar fraction from a fuel combustion sample in a Salmonella Forward Mutation Assay without exogenous metabolic activation, Mutat. Res. 391 (1997) 117-125.

[25] A. Gold, E. Eisenstadt, Metabolic activation of cyclopenta[ $[c d]$ pyrene to 3,4 -epoxycyclopenta[ $[c d]$ pyrene by rat liver microsomes, Cancer Res. 40 (1980) 3940-3944.

[26] A.W. Bartczak, R. Sangaiah, L.M. Ball, S.H. Warren, A. Gold, Synthesis and bacterial mutagenicity of the cyclopenta oxides of the four cyclopenta-fused isomers of benzanthracene, Mutagenesis 2 (1987) 101-105.

[27] R. Sangaiah, A. Gold, L.M. Ball, L.M. Kohan, B.J. Bryant, K. Rudo, L. Claxton, S. Nesnow, Biological activity and metabolism of aceanthrylene and acephenanthrylene, in: $\mathbf{M}$. Cooke, A.J. Dennis (Eds.), Polynuclear Aromatic Hydrocarbons: Chemistry, Characterization and Carcinogenicity, Battelle Press, Colombus, Ohio, 1986, pp. 795-810.

[28] E.B. Ledesma, M.A. Kalish, M.J. Wornat, P.F. Nelson, J.C. Mackie, Observation of cyclopenta-fused and ethynylsubstituted PAH during the fuel-rich combustion of primary tar from a bituminous coal, Energy Fuels 13 (1999) 1167-1172.

[29] A.L. Lafleur, J.B. Howard, E.F. Plummer, K. Taghizadeh, A. Necula, L.T. Scott, K.C. Swallow, Identification of some novel cyclopenta-fused PAH in ethylene flames, Polycycl. Aromat. Compd. 12 (1998) 223-237.
[30] M.J.S. Dewar, E.G. Zoebisch, E.F. Healy, J.J.P. Stewart, AM1: a new general purpose quantum mechanical molecular model, J. Am. Chem. Soc. 107 (1985) 3902-3909.

[31] B.N. Ames, J. McCann, E. Yamasaki, Methods for detecting carcinogens and mutagens with the Salmonella/Mammalianmicrosome mutagenicity test, Mutat. Res. 31 (1975) 347-364.

[32] D.M. Maron, B.N. Ames, Revised methods for the Salmonella Mutagenicity Test, Mutat. Res. 113 (1983) 173-215.

[33] O.H. Lowry, N.J. Rosebrough, A.L. Farr, R.J. Randall, Protein measurement with the folin phenol reagent, J. Biol. Chem. 193 (1951) 265-275.

[34] H.M. Wortelboer, C.A. de Kruif, A.A.J. van Iersel, H.E. Falke, J. Noordhoek, B.J. Blaauboer, The isoenzyme pattern of cytochrome $\mathrm{P} 450$ in rat hepatocytes in primary culture, comparing different enzyme activities in microsomal incubations and intact monolayers, Biochem. Pharm. 40 (1990) 2525-2534.

[35] B.S. Kim, B.H. Margolin, Statistical methods for the Ames Salmonella Assay: a review, Mutat. Res. 436 (1999) 113-122.

[36] L. Claxton, J. Allen, A. Auletta, K. Mortelmans, E. Nestmann, E. Zeiger, Guide for the Salmonella typhimurium/Mammalian microsome tests for bacterial mutagenicity, Mutat. Res. 189 (1987) 83-91.

[37] N.F. Cariello, W.W. Piegorsh, The Ames test: the two-fold rule revisited, Mutat. Res. 133 (1996) 23-31.

[38] M. Sarobe, J.W. Zwikker, J.D. Snoeijer, U.E. Wiersum, L.W. Jenneskens, Preparative flash vacuum thermolysis. A short synthesis of cyclopenta[ $[c d]$ pyrene, J. Chem. Soc., Chem. Commun. (1994) 89-90.

[39] M. Sarobe, S. Flink, L.W. Jenneskens, B.L.A. van Poecke, J.W. Zwikker, Cyclopent $[f g]$ acepyrylene, cyclopent $[j k]$ acepyrylene and cyclopent $[\mathrm{mn}]$ acepyrylene: novel $\mathrm{C}_{20} \mathrm{H}_{10}$ cyclopenta-fused PAH, J. Chem. Soc., Chem. Commun. (1995) 2415-2416.

[40] T. Visser, M. Sarobe, L.W. Jenneskens, J.W. Wessseling, Identification of isomeric PAH in pyrolysates from ethynylated PAH by gas chromatography-Fourier IR spectroscopy. Their relevance for the understanding of PAH rearrangement and interconversion processes during combustion, Fuel 77 (1998) 913-920.

[41] M. Sarobe, H.C. Kwint, T. Fleer, R.W.A. Havenith, L.W. Jenneskens, E.J. Vlietstra, J.H. van Lenthe, J.W. Wessseling, Flash vacuum thermolysis of acenaphtho[1,2-a] acenaphthylene, fluoranthene. Benzo[k]- and benzo[j]fluoranthene-homolytic scission of carbon-carbon single bonds of internally fused cyclopenta moieties at $T>1000^{\circ} \mathrm{C}$, Eur. J. Org. Chem. (1999) 1191-1200.

[42] M. Sarobe, Polycyclic aromatic hydrocarbons under high temperature conditions. Consequences for carbon build up during combustion and fullerene formation processes, Ph.D. Thesis, Debye Institute, Utrecht University, Utrecht, The Netherlands, 1998, p. 208.

[43] C. Tintel, J. Cornelisse, J. Lugtenburg, Convenient synthesis of cyclopenta[ $[c, d]$ pyrene and 3,4-dihydrocyclopenta $[c d]$ pyrene. The reactivity of the pyrene dianion, Recl. Trav. Chim. Pays-Bas 102 (1983) 14-20.

[44] P.P.Y. Mulder, Synthesis and spectroscopy of substituted aceanthrylenes and acephenanthrylenes, Ph.D. Thesis, University of Leiden, Leiden, The Netherlands, 1992, p. 159. 
[45] P.P.Y. Mulder, B.B. Boere, A. Baart, J. Cornelisse, J. Lugtenburg, Synthesis and spectroscopy of nine isomeric methylacephenanthrylenes, Recl. Trav. Chim. Pays-Bas. 112 (1993) 22-32.

[46] J.C. Olde, P.P.Y. Mulder, A. van der Gen, G.R. Mohn, J. Cornelisse, J. Lugtenburg, The use of a double Wolff-Kishner reduction in the preparation of aceanthrene and aceanthrylene, Recl. Trav. Chim. Pays-Bas 108 (1989) 79-80.

[47] W. Adam, J. Bialas, L. Hadjiarapoglou, A convenient, preparation of acetone solutions of dimethyldioxirane, Chem. Ber. 124 (1991) 2377-2378.

[48] R.W. Murray, M. Singh, Synthesis of epoxides using dimethyldioxirane: trans-stilbene oxide, Org. Synth. 74 (1997) 91-100.

[49] R.W. Murray, M. Singh, Quantitative synthesis and formation of cyclopenta[ $[c d]$ pyrene-3,4-oxide under simulated atmospheric conditions, Chem. Res. Toxicol. 8 (1995) 239-243.
[50] R.W.A. Havenith, H. Jiao, L.W. Jenneskens, J.H. van Lenthe, P.v.R. Schleyer, M. Kataoka, A. Necula, L.T. Scott, Stability and aromaticity of the cyclopenta-fused pyrene congeners, J. Am. Chem. Soc. 124 (2002) 2363-2370.

[51] E. Steiner, P.W. Fowler, Patterns of ring currents in conjugated molecules: a few electron model based on orbital contributions, J. Phys. Chem. A 105 (2001) 9553-9562.

[52] P.W. Fowler, E. Steiner, A. Acocella, L.W. Jenneskens, R.W.A. Havenith, Mapping the modification of ring currents induced by cyclopenta-fusion on a naphthalene core, J. Chem. Soc., Perkin Trans. 2 (2001) 1058-1065.

[53] M. Lutz, A.L. Spek, M. Sarobe, L.W. Jenneskens, Acefluoranthylene, Acta Cryst. 55 (1999) 659-661.

[54] B. Freiermuth, S. Gerber, A. Riesen, J. Wirz, M. Zehnder, Molecular and electronic structure of pyracylene, J. Am. Chem. Soc. 112 (1990) 738-744. 